\title{
TÜBİTAK Türkiye Adresli Uluslararası Bilimsel Yayınları Teşvik (UBYT) Programının Yeni Destek Algoritmasının Değerlendirilmesi
}

\section{Evaluation of the New Support Algorithm of TÜBITAK's Incentive Program for International Scientific Publications}

\author{
Yaşar Tonta* ve Müge Akbulut**
}

$\ddot{\boldsymbol{O}} \boldsymbol{z}$

TÜBİTAK, Türkiye adresli yayınların sayısını, kalitesini ve etkisini artırmak amactyla 1993 yllında Web of Science'ta (WoS) dizinlenen çalışmaların yazarlarının desteklendiği Türkiye Adresli Uluslararası Bilimsel Yayınları Teşvik (UBYT) Programını uygulamaya koymuştur. Program çerçevesinde destek verilecek yayınlar ve destek miktarlarl saptanırken uygulanan algoritmada zaman zaman değişiklikler yapılmaktadır. Bu bağlamda 2019 yılında uygulanan UBYT Programının yeni destek algoritması, bir önceki algoritmanın aksayan yönlerini düzeltmeyi hedeflemektedir. Bu çalışmada yeni destek algoritmasının desteklenen dergiler, yayınlar ve ödeme miktarları üzerine etkileri karşılaştırmalı olarak incelenmektedir. Bu amaçla önce eski ve yeni destek algoritmalarının işleyişi karşılaştırılmaktadır. Daha sonra yeni algoritmanin etkileri UBYT'nin desteklenen dergi listeleri ve 2015 yllinda desteklenen ve makale etki puanı (MEP) olan yayınlar aracılı̆̆lyla ayrıntılı olarak analiz edilmektedir. Bulgular etki değeri nispeten düşük olan yayınların daha çok desteklenmesi, destek miktarlarında disiplinler arası farklılıklar vb. gibi süregelen sorunların yeni destek algoritmasıyla henüz tam olarak çözülemediğini göstermektedir. Bulgulara dayanarak yayınların etki değerini ölçmek için sadece bibliyometrik ölçevlerin kullanıldığı araştırma destek programlarının karşı karşıya kaldı̆̆ sorunlar tartışılmakta ve bazı öneriler sunulmaktadir.

Anahtar Sözcükler: TÜBİTAK UBYT Programı; performansa dayalı araştırma destek sistemleri; bibliyometrik ölçevler; makale etki puanı.

\begin{abstract}
TÜBITTAK has introduced the Incentive Program for International Scientific Publications (UBYT) in 1993 in order to increase the quantity, quality and impact of TR-addressed publications indexed in Web of Science (WoS) and support their authors. Some changes take place from time to time in the algorithms used in the program to identify publications to be supported and to calculate the amounts of monetary support to be paid. The new support algorithm introduced in 2019 aims to improve the shortcomings of the previous one. This paper
\end{abstract}

\footnotetext{
* Prof. Dr., Hacettepe Üniversitesi, Bilgi ve Belge Yönetimi Bölümü, Türkiye. E-posta: yasartonta@ gmail.com Professor, Hacettepe University, Department of Information Management, Turkey.

${ }^{* *}$ Arş. Gör., Ankara Yıldırım Beyazıt Üniversitesi, Bilgi ve Belge Yönetimi Bölümü, Türkiye. E-posta: mugeakbulut@gmail.com

Research Assistant, Ankara Yildurtm Beyazut University, Department of Information Management, Turkey.
} 
is a comparative investigation of the impact of the new algorithm on supported journals, publications and the amounts of payments. For this, we first compare the functioning of the old and new support algorithms. We then analyze the impact of the new algorithm on the Program's supported journals lists as well as on the publications having article influence scores (AIS) that were supported in 2015 according to the old algorithm. Findings show that ongoing problems such as providing relatively more support to low impact publications and paying different amounts to publications in different fields do not seem to have completely been solved with the new algorithm. We discuss the major issues with performance-based research funding systems that solely use bibliometric measures to determine the impact of publications and offer some suggestions.

Keywords: TÜBITAK's UBYT Program; performance-based research funding systems; bibliometric measures; article influence score.

\section{Giriş}

TÜBİTAK'ın 1993 yılından itibaren Türkiye Adresli Uluslararası Bilimsel Yayınları Teşvik (UBYT) Programı çerçevesinde Science Citation Index'te (SCI) dizinlenen dergilerde yayın yapan araştırmacıları desteklemeye başlaması ve Yükseköğretim Kurulu'nun (YÖK) 2000'lerin başında akademik yükseltme ölçütleri arasına "indeksli dergiler"de uluslararası yayın yapmayı eklemesiyle birlikte performansa dayalı araştırma destek sistemleri Türkiye'deki üniversitelerin gündemini işgal etmeye başlamıştır (Tonta, 2017a, s. 450). YÖK daha sonra uluslararası yayın yapan araştırmacıları Akademik Teşvik Ödeneği Yönetmeliği (2015) çerçevesinde ayrıca desteklemeyi kararlaştırmıştır. Fakat söz konusu araştırma destek programlarıyla ilgili kapsamlı etki analizi araştırmaları henüz yok denecek kadar azdır.

Başlangıcından bu yana TÜBİTAK UBYT Programında ve destek algoritmasında belirli aralıklarla bazı değişiklikler yapılmaktadır. Ancak uzun yıllar bu programla ilgili kapsamlı bir değerlendirme yapılmamıştır. Yakın zamanda yapılan bir çalışmada program çerçevesinde yazarlara yapılan destek ödemeleri analiz edilmiş ve destek algoritmasının aksayan yönleri ortaya çıkarılmıştır (Tonta, 2017b). Bu çalışmanın bulguları nispeten daha az kaliteli dergilerde yayımlanan çalışmaların yazarları desteklenirken makale etki puanları dünya ortalamasının $(1,000)$ üzerinde olan makalelerin yazarlarının daha az desteklendiğini, teşvik miktarlarının çoğu yazar için giderek teşvik edici olmaktan çıktığını göstermiştir. 2019 yılında programda yeniden önemli değişiklikler yapılmış, desteklenecek dergilerin saptanmasında ve teşvik tutarlarının hesaplanmasında kullanılan parametreler güncellenmiş, en düşük ve en yüksek ödeme miktarları yeniden belirlenmiş ve yeni bir destek algoritması geliştirilmiştir (TÜBİTAK, 2019a). Yeni algoritmayla etki değeri düşük dergilerde yayımlanan makalelere "mikro ödemeler" yapılmasına son verilmesi, etki değeri nispeten daha yüksek Q1 ve Q2 dergilerinde yapılan yayınların yazarlarının daha fazla desteklenmesi hedeflenmiştir.

Bu çalışmanın amacı TÜBİTAK UBYT Programının 2019 yılından itibaren uygulanan yeni destek algoritmasını kapsamlı bir biçimde incelemek ve bir önceki destek algoritmasıyla karşılaşıırmaktır. Bu bağlamda dergilerin makale etki puanlarının performans göstergesi olarak kullanılması ve buna dayanan destek algoritmaları geliştirilmesinin farklı alanlardaki yayınlar üzerindeki etkileri ödeme verilerine dayanarak incelenmektedir. Eski algoritmaya göre yeni destek algoritmasının olumlu ve olumsuz yönleri tartışılmakta ve bazı öneriler sunulmaktadır. 


\section{Literatür Değerlendirmesi}

1980'lerde ortaya çıkan performansa dayalı araştırma destek sistemlerinin kullanımı dünyada özellikle son 25 yılda büyük bir hızla artmıştır (European Commission, 2010; Hicks, 2012; Wilsdon ve diğerleri, 2015; Wouters ve diğerleri, 2015). Bu sistemlerde performans göstergesi olarak genellikle yayın ve atıf sayıları, yayınların yer aldığı dergilerin etki faktörleri, makale etki puanları gibi yayın ve dergi düzeyi bibliyometrik ölçevler (metrics) kullanılmaktadır (Sugimoto ve Larivière, 2018). Araştırmacıların ve araştırma birimlerinin (bölüm, üniversite, vd.) yayınları çoğu zaman gerçekleşen (ex post) performanslara göre değil tahmin edilen (ex ante) performanslara göre desteklenmektedir. Performansa dayalı araştırma destek sistemlerinde bibliyometrik ölçevlerin performans göstergesi olarak kullanılmasının temel nedenleri, bu verilerin genellikle ticari veri tabanlarından kolayca elde edilebilmesi ve "akran değerlendirmesi” (peer review) ile karşılaştırıldığında daha kısa zamanda ve daha az maliyetle gerçekleştirilebilmesidir (Tonta ve Akbulut, 2020a).

Ancak son yıllarda özellikle bibliyometrik ölçevlerin kullanıldığı performansa dayalı araştırma destek sistemleri birçok yönüyle sorgulanmaktadır (örneğin, Zhang, Rousseau ve Sivertsen, 2017). Çünkü performans odaklı destek sistemleri genel olarak nitelik yerine niceliği ön plana çıkarmakta ve performansı ölçülen kişiler veya birimler bu duruma uyum sağlamaktadır. Dolayısıyla bir süre sonra performans göstergeleri esas ölçülmek istenen özellikleri ölçemez hale gelmektedir. "Goodhart Yasası” olarak adlandırılan bu olgu kişilerin davranışlarını da değiştirmekte ve etik ihlallere yol açmaktadır. Performansın sadece bazı nicel göstergelere göre ölçülmesi eğitim, sağlı, güvenlik vb. gibi birçok alanda giderek "sayıların diktatörlüğüne” yol açmaktadır (Muller, 2019; Tonta, 2018a; Tonta ve Akbulut, 2020b).

Genelde performans odaklı destek sistemlerinde görülen olumsuz etkiler performansa dayalı araştırma destek sistemlerinde de gözlenmekte, bu sistemlerin de bazı "yan etkileri" bulunmaktadır (Geuna ve Martin, 2003). Destek ile yayınların aldığı atıf sayısı arasında negatif korelasyon gözlendiği için "nakit ödemeler araştırma kalitesinin düşmanı” olarak görülmektedir (Harley ve diğerleri, 2016; Hedding, 2019). Bazı araştırmacılar araştırma alanlarından (fen bilimleri, sosyal ve insani bilimler) bağımsız olarak giderek daha çok sayıda yayın yapmaya, kısa dönemde yayınla sonuçlanacak alanlarda çalışmaya, uzun dönemli nispeten riskli araştırma problemlerinden kaçınmaya yönelmektedirler.

Öte yandan farklı disiplinlerdeki araştırmacı ve yayın sayıları, yapılan yayın türleri (makale, kitap, konferans bildirisi vd.), yayın ve atıf yapma örüntüleri birbirinden oldukça farklıdır. Ama yayınların performans göstergesi olarak kabul edilen etki değerleri hesaplanırken alanlar arasındaki bu farklar genellikle pek dikkate alınmamaktadır (Al, Şahiner ve Tonta, 2006; de Rijcke ve diğerleri, 2016; Hicks, 2004; Sivertsen, 2016, 2019). Bu durum araştırma çıktılarının daha çok destek verilen ve dizinlenen mecralarda (dergiler) ve dillerde (İngilizce) yayımlanmasına yol açmakta, yerel mecralarda ve dillerde yayımlanan araştırmaların sayısı giderek azalmaktadır. Performans ölçütlerini sağlamak için bazı araştırmacılar gerekirse değerlendirme sistemleriyle "oynamaya", destek sistemlerinden daha çok yararlanmak için "fırsatçı davranışlar" geliştirmeye, "atıf çiftlikleri” (citation farms) oluşturmaya başlamışlardır. Buna bağlı olarak kopya çekme (intihal), uydurma araştırma rapor etme, "kıyak yazarlık" gibi etik olmayan vaka sayıları da artmaktadır (Tonta ve Akbulut, 2020a, 2020b). 
Araştırma değerlendirme birimlerinin ve karar vericilerin dikkatlerini bu sorunlara çekmek için son yıllarda çeşitli bildirgeler yayımlanmıştır. 2012'de yayımlanan San Francisco Araştırma Değerlendirme Bildirgesinde (San Francisco, 2012) tek tek araştırma makalelerinin ve araştırmacıların kalitesini ölçmek ve araştırmacıların katkılarını değerlendirmek için ya da işe alma, yükseltme ve fonlama kararlarında etki faktörü gibi dergi temelli ölçevlerin kullanılmaması önerilmektedir (Tonta ve Akbulut, 2020b). Dergi etki faktörü “saplantısı"na (impact factor obsession) 2015'te yayımlanan Araştırma Ölçevleri Leiden Bildirgesinde de dikkat çekilmiş ve araştırma değerlendirmede kullanılmak üzere 10 ilke geliştirilmiştir (Hicks ve diğerleri, 2015). Nicel değerlendirmenin, nitel değerlendirmenin yerini almak yerine onu desteklemesi; performans ölçümünde kişi, grup ve kurumların araştırma misyonlarının dikkate alınması; yerel sorunlarla ilgili araştırmaların desteklenmesi; alanlara göre yayın ve atıf uygulamalarının dikkate alınması ve ölçütlerin amaç haline geldiği ve sistemlerle "oynamayı" özendiren değerlendirme ve göstergelerin yan etkilerinin göz önünde bulundurulması bu ilkeler arasında yer almaktadır. Bu bildirgelere rağmen bibliyometrik ölçevlere dayanan araştırma destek sistemleri halen dünyada birçok ülkede kullanılmaktadır. Hatta bazı ülkelerde atıf dizinlerinde listelenen dergilerde yayımlanan makaleler için çok yüksek miktarlarda ödemeler yapilmaktadır (Tonta ve Akbulut, 2020b).

Ancak yapılan araştırmalarda bibliyometrik ölçevlere dayanan araştırma destek sistemlerinin yayın sayısını bir miktar artırsa da yayınların etki değerini pek artırmadığı ortaya çıkmıştır (örneğin, Auranen ve Nieminen, 2010; Butler, 2003, 2004; Checchi, Malgarini ve Sarlo, 2019). Araş̧ırma destek sistemleri genellikle etkiyi ençoklamak (impact maximization) yerine çıktı sayısını ençoklamak (output maximization) için kullanılmaktadır. Oysa sorun en çok yayın yapanların $\mathrm{m} ı$ yoksa etki değeri yüksek yayın yapanların $\mathrm{m} ı$ ödüllendirilmesi gerektiğinde düğümlenmektedir. Araştırma destek sistemlerinin istenen sonuçları vermemesinin temel nedeni "nicelik ödüllendirilirken niteliğin artmasının ümit edilmesi"dir (Civera ve diğerleri, 2020). Nitelik ümit edildiği gibi artmadığı için de ödül/destek sistemleri işlememektedir (Kerr, 1975, s. 779-780). Bunu gören bazı ülkeler nakit ödemelere dayanan araştırma destek sistemlerini gözden geçirmektedirler. Bu ülkelerden en bilineni Çin'dir. Yakın zamanda "SCI tapınması" (SCI worship) olarak adlandırılan indeksli dergilerde çıkan yayınlara nakit ödeme yapılmasını yasaklayan Çin, WoS temelli göstergelerin performans ölçümü için kullanılmasina son vermeye hazırlanmaktadır (Zhang ve Sivertsen, 2020).

Performansa dayalı araştırma değerlendirme sistemleri Türkiye'de de yaygın bir biçimde kullanılmaktadır. TÜBITTAK UBYT Programı ilk olarak 1993 yılında Science Citation Index (SCI), Chemistry Citation Index (CCI), CompuMath, Index Medicus (IM), Engineering Index (Ei) gibi uluslararası dizinlerde listelenen dergilerde her tür yayın (makale, kitap bölümü, konferans bildirisi, editöre mektup, vd.) yapmayı özendirmek amacıyla başlatılııştır. 2006 yılına kadar sadece fen bilimleri ve tıp alanındaki yayınlar desteklenmiştir. 2006'da Social Sciences Citation Index (SSCI) ve Arts \& Humanities Citation Index'te (AHCI) dizinlenen sosyal bilimler ile sanat ve insan bilimleri dergileri de programa dâhil edilmiştir (Tonta, 2017b, s. 21-23). Daha önce de değinildiği gibi, 2000'lerin başında YÖK yukarıdaki dizinlerde listelenen uluslararası dergilerde alanlara göre en az iki-üç yayın yapmış olmayı doçentlik başvuru ölçütlerinden birisi olarak kabul etmiştir. Bunun yanı sıra birçok üniversitenin 
uluslararası yayın yapan araştırmacıları çeşitli biçimlerde (örneğin, nakit ödeme yapılması, uluslararası konferanslara katılım giderlerinin karşılanması vb. gibi) desteklediği bilinmektedir.

14 Aralık 2015'te yürürlüğe giren ve 2016, 2018 ve 2020'de üzerinde bazı değişiklikler yapılan Akademik Teşvik Ödeneği (ATÖ) Yönetmeliğinde uluslararası yayınlar ve atıflar teşvik ölçütleri arasında oldukça ağırlıklı (\%60) yer tutmakta ve belli bir eşiğin (30) üzerinde puanı olan araştırmacıların maaşlarına her yıl kazanılan puanlar tutarında unvanlarına göre ek ödeme yapılmaktadır (Akademik, 2015, 2016, 2018, 2020). Başlangıçta bütün alanlarda atıf dizinlerinde listelenen dergilerde yayımlanan makalelere dergilerin etki değerlerine bakılmaksızın eşit puan verilirken (Akademik, 2015, 2016), 2018'de dört ana alan belirlenerek fen bilimleri ${ }^{1}$ ile mimarlık alanlardaki yayınlara ve atıflara daha düşük, sosyal ve insani bilimler alanlarındakilere ise daha yüksek puanlar verilmeye başlanmıştır. Aynı yıl puan hesaplanmasında dergilerin ULAKBİM puanı esas alınmaya başlanmıştır (Akademik, 2018, Md. 8(6)). Ancak ULAKBİM, 2019' da uygulanmaya başlanan yeni destek algoritmasında dergi puanlarını hesaplama formülünü değiştirince ATÖ Yönetmeliği de değiştirilmiş ve puan hesaplamasında dergilerin Journal Citation Reports'ta (JCR) listelenen çeyreklik (quartile) değerleri esas alınmaya başlanmıştır (Q1 en yüksek, Q4 en düşük \%25'lik dilim). Çeyreklik değerleri listelenmeyen AHCI dergilerinde yapılan yayınların puanları ise Q3 değeri katsayıs1 $(0,5)$ üzerinden hesaplanmaktadır (Q1'in katsayısı 1'dir) (Akademik, 2020, Md. 4(6)). ${ }^{2}$

YÖK'ün doçentlik başvurularında uluslararası yayın yapmış olma koşulu koymasının Türkiye'de bilimsel araştırmaların niteliğini nasıl etkilediği konusunda henüz kapsamlı bir değerlendirme yapılmamıştır. Nispeten daha yeni bir uygulama olmasına karşın ATÖ Yönetmeliğiyle ilgili birçok çalışma yapılmıştır. Bu çalışmalar daha çok akademisyenlerin teşviklerle ilgili görüş ve algıları, teşviklerin motivasyon ve sosyo-ekonomik rahatlama sağlayıp sağlamadığı, uygulamanın başlamasıyla birlikte akademik teşvik puanı ortalamalarının yükselip yükselmediğiyle ilgilidir (örneğin, Akın, 2018; Göksu ve Bolat, 2019; Yokuş, Ayçiçek ve Kanadlı, 2018). Uygulamanın ulusal ve uluslararası yayın sayısını artırdığı, ancak (ulusal kongrelerin uluslararası olarak adlandırılması, yağmacı dergilerde yayın yapılması vb. gibi) bazı etik sorunlara da yol açtığı gözlenmiştir (Demir, 2018a, 2018b, 2018c; Koçak, 2019). Ancak akademik teşvik puanlarının hesaplanmasını önemli ölçüde etkileyen bibliyometrik ölçevleri sorgulayan çalışmaların henüz gerçekleştirilmediği anlaşılmaktadır.

TÜBİTAK UBYT Programı ise daha çok 2012 öncesi ve sonrasında dergilerin sınıflandırılmasında yapılan değişikliklerin farklı alanlara (arkeoloji, yer bilimleri, kimya, ekonomi) ve ödeme miktarlarına yansıması (Batmaz, 2013; Taşkın, 2020; Tonta, 2014a, 2015; Yaltırak, 2014; Yuret, 2016) yönlerinden incelenmiştir. Örneğin, kimya konulu dergilerde yayın yapan araştırmacılara, ekonomi dergilerinde yayın yapanlara oranla ortalama dört kat daha fazla ödeme yapıldı̆̆ anlaşılmaktadır (Yuret, 2016). Program 1997-2015 yıllarındaki ödeme verilerine dayanarak kapsamlı bir biçimde değerlendirilmiş, programın Türkiye adresli yayınların sayısının artmasında bir etkisi olmadığı ve destek verilen yayınların verilmeyenlere oranla daha yüksek sayıda atıf almadıkları ve etki değeri daha yüksek dergilerde yayımlanmadıkları ortaya çıkarılmıştır (Tonta, 2017b, 2018b; Tonta ve Akbulut, 2020a).

\footnotetext{
${ }^{1}$ Eğitim bilimleri, fen bilimleri grubunda yer almaktadır.

${ }^{2}$ ULAKBİM'in eski ve yeni destek algoritmalarında kullanılan puan hesaplama formülleri Bulgular ve Yorum kısmında ayrıntılı olarak incelenmektedir.
} 
Araştırmacıların UBYT desteğini hedefleyerek yayın yapmadıklarını ve buna göre yayın yapma davranışlarını değiştirmediklerini gösteren bir çalışma bu bulguları destekler niteliktedir (Yuret, 2017).

Doğrudan TÜBITTAK UBYT destek algoritmalarının işleyişini inceleyen çalışmalar oldukça azdır (Tonta, 2014a, 2015; Yuret, 2016, 2017). 1993-2015 y1lları arasındaki TÜBİTAK UBYT Programı Uygulama Usul ve Esaslarındaki değişiklikler ve dergilerin makale etki puanlarına göre destek algoritmasının işleyişi farklı disiplinlerdeki dergilerde yayımlanan makalelere yapılan ödemelere dayanarak kapsamlı bir biçimde 2017'de incelenmiştir (Tonta, 2017b, s. 21-26, 71-99). Ama 2019'da uygulanmaya başlanan yeni destek algoritması üzerine kapsamlı bir çalışma henüz yapılmamıştır. Bu çalışmada daha önce (Tonta, 2017b) incelenen ve 2019 yılına kadar kullanılan eski destek algoritmasının işleyişiyle 2019 yılından itibaren uygulanmaya başlanan yeni algoritmanın işleyişi 2015 yılı ödeme verilerine dayanarak karşılaştırılmaktadır.

\section{Yöntem ve Veri Kaynakları}

$\mathrm{Bu}$ çalışmanın temel araştırma sorusu TÜBİTAK UBYT Programının yeni destek algoritmasının etkinliğini bir önceki destek algoritmasının etkinliğiyle karşılaştırarak değerlendirmektir. Eski ve yeni destek algoritmaları (1) UBYT Programı Uygulama Usul ve Esasları; (2) 2015-2020 yıllarına ait UBYT Programı desteklenen dergi listeleri; ve (3) UBYT Programı ödeme verilerine göre karşılaştırılmaktadır.

$\mathrm{Bu}$ çalışmada tanımlayıcı yöntem (descriptive method) kullanılmıştır. Bu yöntem, üzerinde araştırma yapılan olguları tanımlamak ve açıklamak için kullanılır (Schutt, 1999, s. 12). "Tanımlayıcı araştırma yöntemi, yorumlama ile maddi gerçeği bulmaktır" (F.L. Whitney'den aktaran Krishnarao, 1961, s. 46). Araştırmaya konu olan olgu, olay ve nesneler hakkında bir anlayış geliştirmeyi ve genelleme yapmayı amaçlar. Araştırma konusuyla ilgili olarak "ne" ve "nasıl”" soruları üzerinde odaklanan tanımlayıcı araştırmalar, bu yönüyle "niçin" sorusu üzerinde odaklanan ve değişkenler arasında neden-sonuç ilişkisi kurmak için gerçekleştirilen açıklayıcı (explanatory) araştırmalardan önce gelir. Tanımlayıcı yöntemde hem nicel hem de nitel verilerden yararlanılabilir. Bir araştırma süreci olarak tanımlayıcı yöntemde, konuya bakış açılarını açıklığa kavuşturarak işe başlanır; konunun bileşenleri belirlenir ve biçim, düzen ve yapısı analiz edilir; konuyla ilgili uygulamadaki güç ve sistemlere bakılır ve konunun ilerleyen aşamaları çözümlenir. Betimleme araştırmaları (surveys) ve örnek olay incelemelerinde (case studies) tanımlayıcı yöntem kullanılır (Krishnarao, 1961, s. 47-49).

Bu araştırmada tanımlayıcı yöntem, TÜBİTAK UBYT Programının eski ve yeni destek algoritmalarını karşılaştırmak için kullanılmıştır. Önce Programın uygulama usul ve esaslarına dayanarak iki destek algoritmasının işleyişleri karşılaştırılmış ve desteklenen dergilerle ilgili sayısal veriler sunulmuştur. Daha sonra yeni algoritmaya göre 2019 yılında desteklenen dergilerin makale etki puanları ve destek miktarları incelenmiş, farklı alanlara (fen, sosyal bilimler, sanat ve insan bilimleri) göre ödeme miktarları karşılaştırılmıştır. Son olarak eski algoritmaya göre 2015 yılında desteklenen makalelere yapılan gerçek ödemelere dayanarak, aynı makaleler için 2019 yılında da destek için başvurulsaydı bu makalelere yeni algoritmaya göre yapılacak ödeme miktarları analiz edilmiş ve yorumlanmıştır. Böylece eski ve yeni destek 
algoritmalarının benzer ve farklı yönleri ortaya çıkarılmıştır. Aşağıda araştırma süreci ve kullanılan veri kaynakları açıklanmaktadır.

Desteklenen dergi listeleri her yıl TÜBİTAK ULAKBİM sitesinde yayımlanmaktadır. ${ }^{3}$ 2015 yılına ait ödeme verileri TÜBİTAK ULAKBİM'den sağlanmıştır. Desteklenen Türkiye (TR) adresli makalelerin yayımlandığı dergilere ilişkin bibliyometrik veriler (makale etki puanı, çeyreklik, vd.) ise Clarivate Analytics Şirketinin WoS, InCites ve JCR veri tabanlarından derlenmiştir. Veri setinin nasıl oluşturulduğu Şekil 1'de gösterilmektedir.

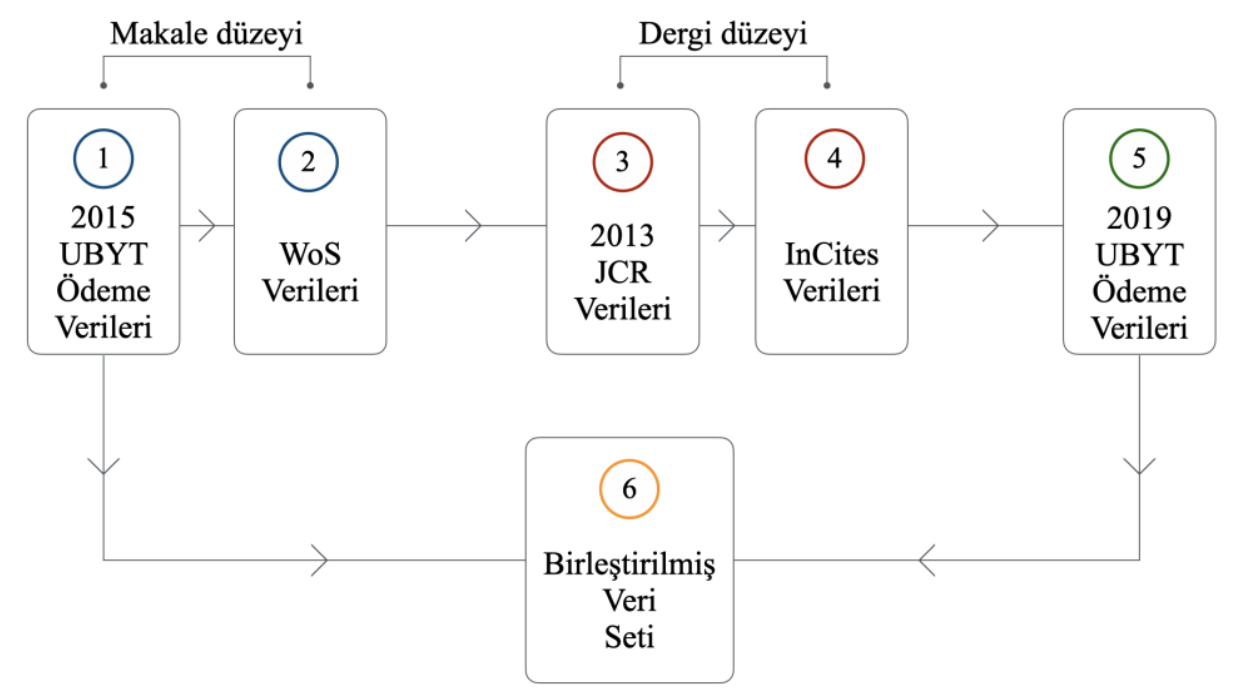

Şekil 1. Verilerin analize uygun hale getirilmesi süreci

2015 yılında 3031 dergide yayımlanan ve desteklenen 9715 TR adresli yayına ait ödeme verileri (Şekil 1, \#1) TÜBİTAK ULAKBİM tarafından sağlanmıştır. Desteklenen yayınlara ait makale düzeyindeki veriler (atıf sayısı, konu kategorisi vd.) WoS atıf veri tabanından indirilmiş (23 Haziran 2019) (\#2) ve iki liste birleştirilmiştir. 2015 yılında desteklenen dergiler ve destek miktarları belirlenirken 2013 yılı JCR verileri (dergi etki faktörü, makale etki puanı, çeyreklik vd.) dikkate aldığından bu veriler dergilerin çeyrekliklerine (Q1, Q2, Q3, Q4) göre ayrı ayrı indirilmiş (\#3), böylece farklı konularda farklı dergi çeyrekliklerine dâhil olan dergilerle ilgili bilgiler elde edilmiştir. 2015 ödeme verileri dosyasına (\#1) veri girişleri elle yapıldığı için bu dosya WoS ve JCR veri setleri ile birleştirilmeden önce bazı standardizasyon işlemleri yapılmış (örneğin, aynı dergiye ait farklı kısaltmalar birleştirilmiştir) ve MS Excel kullanılarak bir benzerlik makrosu hazırlanmıştır. Birleştirme işleminin doğru yapılabilmesi için makrodaki benzerlik oranı yüksek tutulmuş (\%80) ve makro çıtısı birleştirme yapılmadan önce de kontrol edilmiştir. Daha sonra bu verilere InCites’tan alınan dergilerin yayın bilgileri eklenmiştir (\#4).

Eski algoritmaya göre ödeme miktarı dergi nihai puanına (DNP) göre hesaplandığından ULAKBİM'in 2015 yılı ödeme kayıtlarında TR adresli yayınların yer aldığ 1 dergilerin makale etki puanı (MEP) değerleri bulunmamaktadır. Bu yüzden ödeme yapılan yayınlara ait bilgiler JCR verileriyle eşleştirilerek her ödeme kaydına DNP'nin yanı sıra MEP değerleri de veri setine eklenmiştir.

\footnotetext{
${ }^{3}$ Bkz. https://cabim.ulakbim.gov.tr/ubyt/ubyt-uygulama-usul-ve-esaslari-arsivi/ ve https://cabim.ulakbim.gov.tr /ubyt/.
} 
Dergilerin etki faktörleri yıldan yıla pek fazla değişmediğinden (yıllık artış hızı \%3,5 civarındadır) $^{4}$ eski ve yeni destek algoritmalarının karşılaştırmalı analizine dayanan bu çalışmada yayın yılı 2015 olup desteklenen yayınlar için aynı şartlarda destek başvurusu yapılsaydı bu yayınlara 2019' da ödenecek miktarlar dergilerin 2015 y1lı MEP değerlerine göre hesaplanmıştır (\#5). ${ }^{5}$ Böylece 2015 ile 2019 yılları arasında dergilerin MEP değerlerinde meydana gelebilecek küçük değişikliklerden kaynaklanan sorunların giderilmesi amaçlanmıştır. Son olarak yayın türleri (makale ve derleme) de dikkate alınarak 2015 ödeme miktarları 2019 cari fiyatlarına dönüştürülmüş (2019-2021 Dönemi, 2018) ve 2015 ile 2019 veri setleri birleştirilmiştir (\#6).

\section{Bulgular ve Yorum}

\section{TÜBITAK UBYT Programı Uygulama Usul ve Esaslarına Göre Eski ve Yeni Destek Algoritmalarının Karşılaştırılması}

UBYT Programında 2016 yılına kadar kullanılan destek algoritmaları daha önce incelenmiştir (Tonta, 2017b, s. 21-26). Kısaca özetlemek gerekirse; 2013 y1lına kadar desteklenecek dergiler ve bu dergilerde çıkan TR adresli yayınlara yapılacak ödeme miktarları dergilerin JCR'de ilgili oldukları konu kategorileri altında hangi çeyreklikte bulunduğuna göre A (sıralamadaki dergilerin ilk \%25'i), B (ikinci \%25) ve C (son \%50) olarak sınıflandirılmaktaydı. 2013 yılında bu sınıflamaya son verilerek dergilerin beş yıllık etki faktörleriyle bu dergilerde yayımlanan makalelere yapılan atıfların ortalama yarı yaşamı (cited half-life) birbiriyle çarpılarak elde edilen sıralamaya göre destek miktarları belirlenmeye başlandı. Ancak hemen ertesi yıl (2014) bu algoritma da değiştirilerek bir dergide yer alan çalışmaların yayımlandıktan sonraki beş yıl içindeki potansiyel atıf etkisini gösteren MEP'i temel alan bir algoritma kullanılmaya başlandı. 2015 yılında MEP değeri yüksek dergilere daha yüksek miktarlarda ödeme yapılabilmesi için algoritmada küçük bir değişiklik (formülün ikinci kısmında 2. üssü yerine 2,5. üssü alınmaya başlandı) yapılarak maksimum teşvik miktarı (5000 liradan) 7500 liraya yükseltildi ve aşağıdaki destek algoritması 2019 yılına kadar kullanıldı (TÜBİTAK, 2015a; TÜBİTAK, 2015b). ${ }^{6}$

Teşvik $=\min _{\text {teșvik }}+\left(\max _{\text {teșvik }}-\min _{\text {teșvik }}\right) *\left(\frac{\text { dergi nihai puanl }}{100}\right)^{2,5}$

2015 algoritmasında JCR' de yer alan dergilerin MEP değerleri dergilerin yayımlandıkları alanlar da gözetilerek aşağıdaki gibi dergi nihai puanına (DNP) dönüştürülmekteydi:

İlgili yılda, ilgili konu grubuna giren dergiler, makale etki puanı değerlerine göre yukarıdan aşağıya doğru sıralandığında ortalamanın iki standart sapma üzerinde yer alan dergilerin nihai dergi puanı (dergi_nihai_puan) 100 olarak ve ortalamanın iki standart sapma altında yer alan dergilerin nihai dergi puanı (dergi_nihai_puan) ise 0 olarak sabitlenmiş̧tir. Tüm diğer dergilerin

\footnotetext{
${ }^{4}$ Bkz. Fischer ve Steiger (2018).

${ }^{5} 2019$ 'da desteklenen yayınlar ve bu yayınlara yapılan ödeme miktarları yeni algoritmanın işleyişi daha saydam olduğu için kolaylıkla hesaplanabilmektedir.

62016 yılından itibaren uygulama danışman teşviklerini de kapsayacak şekilde genişletilmiştir (TÜBİTAK, 2016a). Ancak 2015 yılında danışman teşviki olmadığından bu çalışmaya dâhil edilmemiştir. 2016-2018 yıllarında UBYT Programı Uygulama Usul ve Esaslarında pek fazla bir değişiklik olmamıştır (TÜBİTAK, 2017a). Hatta 2018 yılına ait esaslar (muhtemelen 2016-2017 ile aynı olduğu için) ayrıca yayımlanmamıştır. Nitekim 2016-20172018 yıllarına ait ödeme parametreleri aynıdır (bkz. https://cabim.ulakbim.gov.tr/ubyt/ubyt-s-s-s/\#).
} 
makale etki puanı, en yüksek puan 100 ve en düşük puan 0 olacak şekilde doğrusal bir transformasyonla dergi_nihai_puan değerlerine dönüştürülmüştür. (TÜBİTAK, 2015b, Ek 1)

MEP değeri olmayan dergiler içinse ilgili yıla ait beş yıllık (o da yoksa iki yıllık) dergi etki faktörü değeri kullanılmaktaydı. Derginin iki yıllık etki faktörü değeri de yoksa o derginin MEP değeri sıfır olarak kabul edilmekte ve bu dergilerde yayımlanan makalelere minimum miktarda (500 lira) destek verilmekteydi (TÜBİTAK, 2015b, Ek 1). (AHCI dergilerinin büyük çoğunluğu JCR listesinde yer almadığı için MEP değerleri bulunmamaktadır.)

Formül 1'deki teşvik miktarı, formülün ilk kısmındaki 7500 (lira) ile DNP'nin 100'e bölündükten sonra bu değerin 2,5. üssünün alınması sonucu elde edilen değerin çarpımına dayanmaktadır. Örneğin, DNP'si 100 olan bir dergide yayımlanan makaleye yapılan ödeme miktarı 7500 liradır $\left.(500+7000) *\left((100 / 100)^{2,5}\right)=(7500 * 1)=7500\right)$.

$\mathrm{Bu}$ algoritmadan beklenen, destek için başvuru sayısı yüksek ama MEP değeri düşük olan dergilerde yayımlanan makalelere daha düşük, başvuru sayısı nispeten düşük ama MEP değeri yüksek olan dergilerde yayımlanan makalelere daha yüksek ödeme yapılmasını sağlamaktı. Bu algoritmada DNP'nin hesaplanması için her ne kadar JCR konu kategorileri altında verilen dergilerin MEP değerlerinden yararlanıldıysa da, MEP değerlerine dayanarak dergiler sıralandıktan sonra her dergi için 0 ile 100 arasında bir DNP hesaplanmakta ve ödeme miktarı buna göre belirlenmekteydi. JCR konu kategorileri altında listelenen dergi sayısı az ise bu kategoriler diğer konu kategorileriyle birleştirilmekteydi. Ancak dergilerin MEP değerlerine dayanarak atanan DNP'lerin hesaplanma yöntemi ile alanında yeterli sayıda dergi olmayan farklı konulardaki dergilerin birleştirilme yöntemi saydam değildi (Yuret, 2016, s. 1200; Tonta, 2017b, 5. Bölüm). Benzer MEP değerlerine sahip dergilerde yayımlanan makalelere dergilerin nihai puanlarının hangi konu altında hesaplandığına bağlı olarak oldukça farklı miktarda ödemeler yapılabilmekteydi.

Eski destek algoritmasıyla ilgili bir diğer sorun -ki bu sorun yeni destek algoritması için de geçerlidir- dergilerin MEP değerlerinin dağılımının çarpık olmasıdır. Başka bir deyişle, çok sayıda derginin MEP değerleri düşük, az sayıda derginin ise nispeten daha yüksektir. Çarpık dağılımın sonucu olarak MEP değeri ortalamanın altında olan dergilerin neredeyse hepsinin formül 1'e göre hesaplanan DNP'leri iki standart sapma (SS) sınırları içerisinde yer almaktaydı. Dolayısıyla SS değerlerine göre yapılan doğrusal dönüştürüm ile hesaplanan DNP'nin 100'e bölünüp 2,5. üssü alındığından bu algoritmanın MEP değeri yüksek olan dergileri baskıladığı ve yeterince ödüllendirmediği; tam tersine MEP değeri nispeten düşük olan ya da MEP değeri olmayan ama WoS'ta dizinlenen dergileri yayın başına konulan minimum ödeme miktarı (500 lira) nedeniyle ödüllendirdiği yönünde bulgular ortaya çıktı (Tonta 2017b, s. 73-76).

2019 yılında UBYT Programı destek algoritması yeniden değiştirildi. DNP uygulamasından vazgeçilerek dergilere yapılacak ödeme miktarlarının dergilerin sadece MEP değerlerine dayandırıldığı aşağıdaki algoritma kullanılmaya başlandı ve maksimum ödeme miktarı 7500 liradan 15.000 liraya yükseltildi (TÜBİTAK, 2019a).

Teşvik $=\left[\right.$ Teşvik $_{a}+\left(\right.$ Teşvik $_{b}-$ Teşvik $\left.\left._{a}\right) *\left(\frac{M E P^{*}-M E P_{a}}{M E P_{b}-M E P_{a}}\right)\right] *($ dergi katsayısı $)$

2019 tarihli yeni algoritmanın ayrıntıları ilgili yıla ait uygulama usul ve esaslarında verilmektedir (TÜBİTAK, 2019a). İlk bakışta karmaşı gibi görünen bu algoritma aslında basittir. Formül, kabul edilen minimum dergi MEP değeri ile MEP değeri 1,500 arasında olan 
dergiler için doğrusal bir biçimde işlemekte ve MEP değerleri bu aralıkta olan dergilerde yayımlanan makalelere minimum 500 lira (Teşvika) ile 7500 lira (Teşvikb) arasında ödeme yapılmaktadır. Minimum MEP değeri 2019 yllında JCR'de listelenen ve Türkiye'de yayımlanan dergiler için $\left(M E P_{a}\right)$ 0,100, yabancı ülkelerde yayımlanan dergiler içinse 0,250 $\left(M E P_{e}\right)$ olarak kabul edilmiştir. Formül 2'deki $M E P_{b}$ değeri 1,500 olarak saptanmıştır. $M E P^{*}$ değeri ise teşvik miktarı hesaplanacak her dergi için kullanılmaktadır. Formüldeki "dergi katsayısı" Türkiye'de yayımlanan ve JCR'de listelenen dergilerde yayımlanan makalelere "pozitif ayrımcılık" yapmak için kullanılmaktadır. Dergi katsayısı yabancı dergiler için 1, Türkiye'de yayımlanan dergiler için 1,5, TÜBİTAK dergileri için ise 2 olarak belirlenmiştir. ${ }^{7}$ Böylece Türkiye'deki dergilerde ve TÜBİTAK dergilerinde yayımlanan makalelere sırasıyla $\% 50$ ve \%100 daha fazla ödeme yapılmaktadır. Örneğin, bu algoritmaya göre 2019 yllında MEP değeri $\left(M E P^{*}\right)$ 0,500 olan ve (a) yurt dışında yayımlanan bir dergiye 2500 lira; (b) Türkiye'de yayımlanan bir dergiye 3750 lira; ve (c) bir TÜBITTAK dergisine 5000 lira ödenmektedir. ${ }^{8}$

2019 yılında MEP değeri 1,500 ve üzerinde olan dergiler için ise üç sabit ödeme miktarı belirlenmiştir: MEP değeri (a) 1,500 $\left(M E P_{b}\right)$ ile 2,000 $\left(M E P_{c}\right)$ arasinda olan dergiler için 7500 lira (Teşvikb); (b) 2,000 ile 3,000 (MEPd) arasında olan dergiler için 10.000 lira (Teşvikc); ve (c) 3,000'den yüksek dergiler için ise 15.000 lira (Teşvikd) olarak belirlenmiştir. MEP değerleri olmayan ama JCR'de Q1 ve Q2 dergileri olarak listelenen dergiler için sırasıly 7500 lira (Teşvikb) ve 3750 lira (Teşvikb'nin yarısı) ödenmesi kararlaştırılmıştır. MEP değerleri hesaplanmayan sanat ve insan bilimleri dergilerinde (AHCI) yayımlanan makaleler için ise 2000 lira sabit destek miktarı belirlenmiştir. AHCI'nin yanı sıra SSCI ve/veya SCI-E'de de listelenen ve dolayısıyla MEP değerleri hesaplanan dergilerde yayımlanan makaleler içinse MEP değerlerine göre hak edilen ödeme miktarı kullanılmaktadır (2000 liranın üzerinde olmak kaydıyla). Bu miktarlar makaleler için geçerlidir. Derleme yayınlara ise bu miktarların yarısı ödenmektedir. 2019'da yazar teşvik paylaşım eşiği için dergi MEP değeri $\left(M E P_{y}\right)$ 1,000 olarak belirlenmiştir. MEP değeri 1,000'e kadar olan yayınlarda kişi başına ödeme miktarını bulmak için yabancı adresli yazarlar (yani toplam ortak yazar sayısı) dikkate alınmakta, MEP değeri 1,000 'den yüksek yayınlar içinse kişi başına ödeme miktarı sadece TR adresli yazar sayısına göre belirlenmektedir. Bir yazara yapılacak en düşük ödeme miktarı 250 lira olarak saptanmış, bir yazarın bir yayın yılı içinde yapabileceği başvuru sayısı ise 10 ile sınırlandırılmıştır.

2020 yılında yeni algoritmada -muhtemelen başvuru sayısını azaltmak amacıyla- bazı değişiklikler yapılmıştır. Destek başvurusu yapabilmek için gereken minimum dergi MEP değeri Türkiye'de yayımlanan dergiler $(0,100)$ ve SSCI'de dizinlenen dergiler $(0,250)$ için değişmemiş ama SCI-E'de dizinlenen dergiler için 0,500 'e yükseltilmiştir. Yazar teşvik paylaşım eşiği için dergi MEP değeri $\left(M E P_{y}\right)$ 1,000'den 1,500'e yükseltilmiş, yazarların bir yıl içinde yapabilecekleri başvuru sayısı kısıtlaması (10) MEP değeri 1,000 ve üzerindeki dergilerdeki yayınlar için kaldırılmıştır (TÜBİTAK, 2020a). Ancak MEP değeri 1,000'in altında olan dergilerde yapılan yayınlar için bir yazarın alabileceği toplam destek miktarı 5000 lirayı geçmeyecek şekilde sınırlandırılarak MEP değeri dünya ortalamasının $(1,000)$ üzerindeki dergilerde yayın yapan yazarların daha fazla desteklenmesi amaçlanmıştır. Ortak yazarlı

\footnotetext{
${ }^{7}$ 2016-2020 yılları arasındaki UBYT ödeme parametreleri için bkz. https://cabim.ulakbim.gov.tr/ubyt/.

${ }^{8}$ UBYT 2019 dergi listesinde Türkiye'de yayımlanan ve JCR'de listelenen MEP değeri en yüksek dergi $(0,605)$ Journal of Sports Science and Medicine dergisidir (4538 lira).
} 
yayınlara yapılacak ödemeler de bazı koşullara bağlanmıştır. Ortak yazarlar arasında destek miktarının nasıl paylaştıılacağı yukarıda anılan yazar teşvik paylaşımı için dergi MEP değerinin $\left(M E P_{y}=1,500\right)$ yanı sıra yazar sayısı eşik değerine (10) de bağlıdır. MEP değeri 1,500'ün altında olan dergiler için destek miktarı hesaplanırken TR adresli olmayan yazarlar da dikkate alınmaktadır. MEP değeri 1,500 ve üzerindeki dergilerde ise sadece TR adresli yazarlar dikkate alınmaktadır. Destek miktarı buna göre TR adresli yazarlar arasında eşit olarak paylaştırılmaktadır. Ama bir yayının ortak yazar sayısı 10'un üzerindeyse TR adresli yazar başına yapılacak maksimum ödeme miktarı 3000 lira ile sınırlandırılmıştır. ${ }^{9}$

\section{TÜBITTAK UBYT Programı Desteklenen Dergi Listeleri ve Yeni Destek Algoritması}

TÜBİTAK ULAKBİM her yıl JCR verilerine dayanan desteklenecek dergi listesini web sayfası aracılığıyla yayımlamaktadır. Bu listede ilgili dergilerde yayımlanacak makalelere ve diğer yayınlara yapılacak destek miktarı ve dergilerin bazı özellikleri yer almaktadır. Bu kısımda 2019 yılında yapılan algoritma değişikliğinin UBYT Programınca desteklenen dergi listelerine yansımaları üzerinde durulmakta ve eski algoritmayla yeni algoritmanın uygulanması sonucu desteklenen dergilerin sayıları ve bibliyometrik özellikleriyle ilgili karşılaştırmalar yapilmaktadir.

Eski destek algoritmasının uygulandığı son yıla (2018) kadar desteklenen dergi sayısı yavaş da olsa sürekli bir artış göstermiş, ancak yeni algoritmanın uygulanmaya başlanmasıyla birlikte desteklenecek dergiler için getirilen dergi makale etki puanı (MEP) eşik değeri uygulaması nedeniyle dergi sayısı 2019'da \%19, 2020'de ise \%17 oranında düşmüştür (Tablo 1). Başka bir deyişle, desteklenen dergi sayısı iki yılda üçte bir oranında azalmıştır. 2019 yılında önce MEP değeri 0,250'nin (ya da dergi Türkiye'de yayımlanıyorsa 0,100'in) altında olan 2425 derginin, 2020 yılında da MEP değeri 0,500'ün ve 0,250'nin altında olan toplam 1807 SCI-E ve SSCI dergisinin desteklenmesine son verilmiştir.

2015-2019 yılları arasında WoS'ta dizinlenen TR adresli yayın (makale ve derleme makale) sayıs1 (muhtemelen 15 Temmuz 2016 sonrası bazı üniversitelerin kapatılması nedeniyle) 2017'de bir duraklama göstermiş, ancak 2019'da \%20 oranında artmıştır. TÜBİTAK UBYT Programının 15 Temmuz 2016' daki gelişmelerden çok daha fazla etkilendiği anlaşılmaktadır. 2015 yılı verileriyle karşılaştırıldığında 2016 ve 2017 yıllarında desteklenen yayın ve araştırmacı sayıları ve dolayısıyla toplam destek miktarı yaklaşı üçte bir oranında düşmüştür. Yayın başına desteklenen araştırmacı sayısı ortalama 1,1'dir. 2018 yılında destek başvurusu sayısı bir önceki yıla göre \%62 oranında, toplam ödeme miktarı (23 milyon lira) ise yaklaşık üç kat artmıştır. 2019'da ise destek başvurusu sayısı yaklaşık üçte bir oranında azalmıştır. ${ }^{10}$ ULAKBİM faaliyet raporlarında 2018 ve 2019 yıllarına ait desteklenen yayın ve

\footnotetext{
${ }^{9}$ Yani $M E P_{y}$ değeri 1,500'ün hemen altındaki bir dergide örneğin dokuz ortak yazarlı bir makalenin Türkiye adresli tek yazarına yapılacak ödeme miktarı yaklaşık 830 lira (7500/9), $M E P_{y}$ değeri 1,500 veya hemen üzerindeki bir dergide örneğin 11 ortak yazarlı bir makalenin Türkiye adresli tek ortak yazarına yapılacak ödeme miktarı ise 3000 liradır. Aynı durum, örneğin ATLAS gibi büyük araştırma grupları (örneğin CERN) tarafından yayımlanan çok yazarlı (bazen bu sayı beş bini bulmaktadır) makaleler için de geçerlidir. Böyle bir makalede sadece bir Türkiye adresli yazar varsa bu yazara ödenecek miktar 3000 lirayı geçemez.

${ }^{10} 2019$ yılında destek başvuru sayısının \%62 oranında arttığı, bu artışın yeni destek algoritması uygulamasından kaynaklandığı öne sürülmüştür (TÜBİTAK, 2020b). Rapor edilen sayılar aslında 2017 ve 2018 yıllarına aittir. Yukarıda da belirttiğimiz gibi ULAKBİM Faaliyet Raporunda 2019 yılındaki başvuru sayısında üçte bir oranında bir düşüş söz konusudur (TÜBİTAK, 2019b, s. 43).
} 
araştırmacı sayısı verilmemekle birlikte 2019 yılındaki toplam ödeme miktarı bir önceki yılın ödeme miktarına oldukça yakındır (21 milyon lira). Bu durum muhtemelen hem başvuru sayısının üçte bir oranında azalmasından hem de 2019 yılında maksimum ödeme miktarının 7500 liradan 15.000 liraya çıkarılmış olmasından kaynaklanmaktadır.

Tablo 1

TÜBITAK UBYT Programı destekleriyle ilgili veriler (2015-2020)

\begin{tabular}{crrrrrrr}
\hline Y11 & $\begin{array}{c}\text { Desteklenen } \\
\text { dergi say1S1 }\end{array}$ & $\begin{array}{c}\text { TR adresli } \\
\text { yayın say1s1 }\end{array}$ & $\begin{array}{c}\text { Destek } \\
\text { başvurusu } \\
\text { sayıs1 }\end{array}$ & $\begin{array}{c}\text { Desteklenen } \\
\text { başvuru } \\
\text { sayı1 }\end{array}$ & $\begin{array}{c}\text { Desteklenen } \\
\text { yayın sayıs1 }\end{array}$ & $\begin{array}{c}\text { Desteklenen } \\
\text { araştırmac1 } \\
\text { sayıs1 }\end{array}$ & $\begin{array}{c}\text { Destek } \\
\text { miktar1 } \\
\text { (x1000 TL) }\end{array}$ \\
\hline 2015 & 12390 & 29125 & 19438 & 15298 & 9260 & 10572 & 11000 \\
2016 & 12510 & 31472 & 17528 & 6526 & 6518 & 7269 & 7081 \\
2017 & 12767 & 29764 & 18463 & 10175 & 6798 & 6947 & 7815 \\
2018 & 12890 & 30491 & 29851 & -- & -- & -- & 23290 \\
2019 & 10465 & 36533 & 20826 & -- & -- & -- & 21170 \\
2020 & 8658 & & & & & & \\
\hline
\end{tabular}

Not. İkinci sütundaki veriler UBYT yılllk dergi listelerinden (https://cabim.ulakbim.gov.tr/ubyt/), 4.-8. sütunlardaki sayılar ise TÜBİTAK ULAKBİM yıllık faaliyet raporlarından derlenmiştir (TÜBİTAK 2015b, s. 13; 2016b, s. 48; 2017b, s. 62; 2018, s. 58; 2019b, s. 43). Destek miktarı ilgili yılların cari fiyatlarını yansıtmaktadır. 2019 yılında yayın başına maksimum ödeme miktarı 7500 liradan 15.000 liraya yükseltilmiştir. 2018-2019 yıllarının faaliyet raporlarında desteklenen başvuru sayısı, yayın sayısı ve araştırmacı sayısı verilmemiştir. Üçüncü sütundaki TR adresli yayın sayıları (sadece makaleler ve derleme makaleler) Web of Science'ta 11 Temmuz 2020 tarihinde yapılan taramadan elde edilmiş̧ir. Desteklenen yayın sayısı tekildir. Bir yayın için birden fazla araştırmacı destek için başvurabilmektedir. Desteklenen araştırmacı sayısı tekil değildir.

UBYT'nin 2019 y1lı desteklenecek dergi listesinde 10.465 dergi bulunmaktadır (Tablo 1). Tablo 2'de 10.465 dergi arasından MEP değerleri olan 8678 derginin 0,25 'lik (0,250) MEP değeri dilimlerine göre dağılımı verilmektedir. Bunun yanı sıra her dilimdeki dergilere verilen destek miktarı ile bu miktarın toplam destek miktarına oranları bilgi için verilmektedir. Destek miktarı ve oranları farazidir. Başka bir deyişle, desteklenecek dergi listesindeki her dergide bir TR adresli yayın yapılacağı varsayımına dayanmaktadır. Gerçekte ise (daha sonraki analizlerde de göreceğimiz gibi) listelenen dergilerin önemli bir kısmında hiç TR adresli yayın yapılmamaktadır. MEP değeri olmayan 1787 dergi Tablo 2 ve Şekil 2'de gösterilmemiştir. Bu dergilerin 1604'ü AHCI'de dizinlenmektedir (2000 lira). Geriye kalan 184 dergiyse MEP değerleri olmamasına rağmen Q1 (71 dergi) ve Q2 (113 dergi) dergileri arasında listelendikleri için 7500 ya da 3750 lira ödenen dergilerdir.

2019 dergi listesinde MEP değeri 0,1'in altında olan 23 dergi, MEP değeri 0,1 ile 0,25 arasında ise 27 dergi bulunmaktadır. Bu dergilerin tamamı Türkiye'de ya da TÜBİTAK tarafından yayımlanan ve WoS'ta dizinlenen dergilerdir. TÜBİTAK UBYT Programı Uygulama Usul ve Esaslarında “Journal Citation Reports'ta olup Türkiye adresli olmayan dergilerin arasından belirlenen eşik değerinden ${ }^{11}$ yüksek MEP'e sahip dergiler ve Journal Citation Reports'ta olup Türkiye adresli tüm dergiler" uluslararası bilimsel dergi olarak tanımlanmaktadır (TÜBİTAK, 2019a, Madde 4k). Başka bir deyişle, Türkiye'de yayımlanan ve JCR'de yer alan "Türkiye adresli tüm dergiler" için herhangi bir eşik değeri

\footnotetext{
${ }^{11} 2019$ yılında Türkiye'de yayımlanan ve JCR'de listelenen dergiler için MEP eşik değeri $\left(M E P_{a}\right)$ 0,100, yabancı ülkelerde yayımlanan dergiler için ise 0,250 'dir $\left(M E P_{e}\right)$ (TÜBITTAK 2019b).
} 
bulunmamaktadır. Bu durumda en azından bazı dergiler için yeni destek algoritmasındaki eşik değerinin $\left(M E P_{a}\right)$ pek bir anlamı kalmamaktadır (bkz. formül 2). ${ }^{12}$

\section{Tablo 2}

UBYT 2019 yll dergi listesindeki dergilerin MEP değerlerine ve destek miktarlarına göre dă̆llımı

\begin{tabular}{rrrrrr}
\hline $\begin{array}{c}\text { Yayın başına } \\
\text { pale etki } \\
\text { tam destek } \\
\text { miktar1 (TL) }\end{array}$ & $\begin{array}{c}\text { Dergi } \\
\text { say1s1 }\end{array}$ & $\begin{array}{c}\text { Dergi } \\
\text { yüzdesi } \\
(\%)\end{array}$ & $\begin{array}{c}\text { Destek } \\
\text { miktar1 } \\
(\text { TL })\end{array}$ & $\begin{array}{c}\text { Destek } \\
\text { yüzdesi } \\
(\%)\end{array}$ \\
\hline $0-0,25$ & $0-1250$ & 50 & 1 & 35055 & 0 \\
$0,25-0,5$ & $1250-2500$ & 2858 & 33 & 5315965 & 14 \\
$0,5-0,75$ & $2500-3750$ & 2153 & 25 & 6631575 & 18 \\
$0,75-1$ & $3750-5000$ & 1257 & 14 & 5435825 & 15 \\
$1-1,25$ & $5000-6250$ & 746 & 9 & 4160255 & 11 \\
$1,25-1,5$ & $6250-7500$ & 421 & 5 & 2873330 & 8 \\
$1,50-1,75$ & 7500 & 268 & 3 & 2010000 & 5 \\
$1,75-2$ & 7500 & 192 & 2 & 1440000 & 4 \\
$2-2,25$ & 10000 & 128 & 1 & 1280000 & 3 \\
$2,25-2,5$ & 10000 & 95 & 1 & 950000 & 3 \\
$2,5-2,75$ & 10000 & 69 & 1 & 690000 & 2 \\
$2,75-3$ & 10000 & 56 & 1 & 560000 & 2 \\
$>=3$ & 15000 & 385 & 4 & 5775000 & 16 \\
Toplam & & 8678 & 100 & 37157005 & 101 \\
\hline
\end{tabular}

Not: Yuvarlama hatasından dolayı toplam destek yüzdesi \%100'den farklıdır.

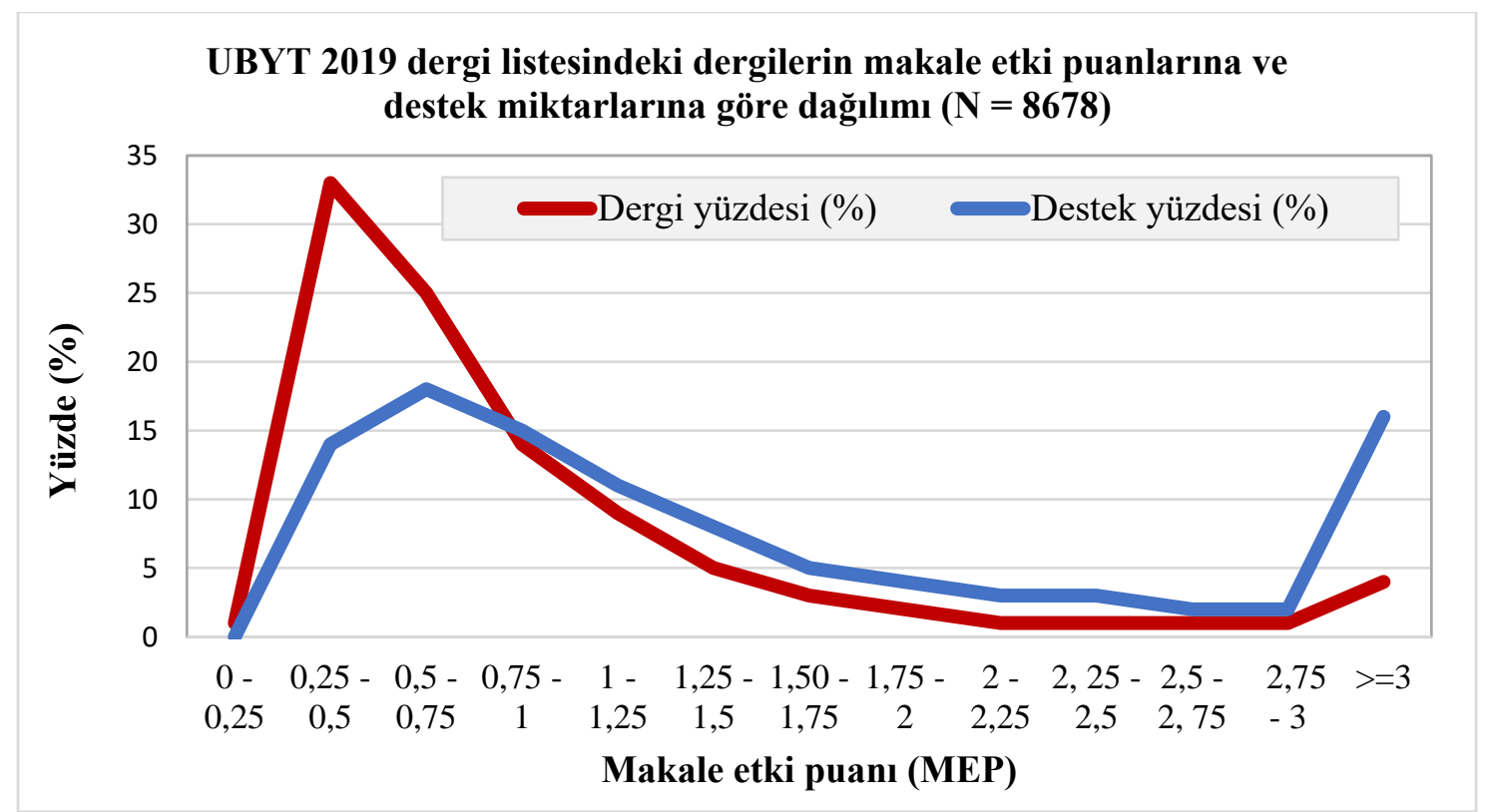

Şekil 2. UBYT 2019 yılı dergi listesindeki dergilerin MEP değerlerine ve destek miktarlarına göre dağılımı

\footnotetext{
${ }^{12} \mathrm{Bu}$ usul ve esaslar dikkate alınacak olursa bu dergilerdeki yayınlara ödeme yapılmaması gerekir. Ayrıca, MEP değerleri eşik değerinden $\left(M E P_{a}\right)$ daha düşük dergiler için formül 2 negatif değerler üretmektedir.
} 
2019'da Türkiye'de yayımlanmayan dergiler için MEP eşik değeri 0,250'ye yükseltildiğinden MEP değeri 0 ile 0,250 arasında olan az sayıda dergi desteklenmektedir. Ancak desteklenen dergilerin gene de üçte birinin MEP değerleri 0,250-0,500 arasında, dörtte üçünün ise MEP değerlerinin dünya ortalamasının $(1,000)$ altında olduğu görülmektedir. Maksimum miktarda (15.000 lira) destek alabilecek dergilerin bütün dergilere oran 12019'da yaklaşık \%4'tür. Fakat bu dergilerde oldukça kısıtlı sayıda TR adresli makale yayımlandığı gözden uzak tutulmamalıdır.

Bu çalışmada 2015 ve 2019 destek algoritmaları karşılaştırıldığından 2020 yılıyla ilgili ayrıntılı bilgi yer almamaktadır. Ancak MEP eşik değeri 2020'de SCI-E dergileri için 0,500'e yükseltildiğinden MEP değeri olan ve desteklenecek toplam dergi sayısı 6988'e düşmektedir. Tıpk1 2019 yılında MEP değerleri 0-0,250 arasındaki dergilerde olduğu gibi, MEP değerleri 0,250-0,500 bandında olan ve desteklenen dergilerin toplam dergilere oranı 2020'de 2019'daki oranın (\%33) yarısına inecektir. Böylece 2019'da MEP değerleri 0,500'ün altında olan ve desteklenen dergilerin toplam dergilere oranı yaklaşık \%33'ten 2020'de \%15'e, MEP değerleri dünya ortalamasının (1,000) altında olan dergilerin oranı da \%73'ten \%66'ya düşecektir.

Şekil 2'deki destek miktarları dikkate alındığında MEP değerleri 0,500'den düşük olan dergiler UBYT dergi listesindeki toplam dergilerin üçte birini oluşturmasına karşın bu dergiler toplam ödeme miktarının \%14'ünü hak etmektedir. Öte yandan MEP değeri üçün üzerinde olan ve toplam dergilerin sadece \%4'ünü oluşturan 385 dergi ise toplam ödeme miktarının \%16'sına hak kazanmaktadır. Ancak MEP değeri yüksek dergilerde oldukça kısıtlı sayıda TR adresli makale yayımlandığından gerçek ödeme yüzdesi bunun çok altında gerçekleşmektedir. Gerçek ödeme verileri üzerinden bir değerlendirme aşağıda yapılmaktadır.

Bir önceki kısımda da değinildiği gibi, UBYT Programı destek algoritmalarında dergilerin etki faktörlerinin ya da makale etki puanlarının normal dağıldığı varsayılmaktadır. Bu varsayım 2019 yılındaki yeni destek algoritması için de geçerlidir. Yeni destek algoritması dergiler için MEP değeri 1,500'e kadar doğrusal olarak artan ödeme yapılmasını öngörmektedir. Oysaki Şekil 2'de de görüldüğü gibi dergilerin MEP değerlerinin dağılımları son derecede çarpıktır. Desteklenecek dergi listesindeki dergilerin yaklaşık dörtte üçünün MEP değerleri 1,000'in, \%87'sinin ise 1,500'ün altındadır.

Öte yandan, bir derginin MEP değeri o derginin fen bilimleri, sosyal bilimler ya da sanat ve insani bilimler dergisi olmasına göre de değişmektedir. Çünkü bu disiplinlerde yayımlanan dergi sayıları, bilimsel iletişim mecraları (dergi makalesi, kitap vs.), araştırmacı sayıları vs. birbirinden oldukça farklıdır. Daha önce de belirtildiği gibi fen bilimlerinde ya da sosyal bilimlerde farklı konulardaki dergilerin atıf örüntüleri bile birbirinden farklı olabilmektedir. 2019 yılı UBYT dergi listesi üzerinden bir karşılaştırma yapmak gerekirse, desteklenen dergilerin \%60'1 (6245) sadece SCI-E'de dizinlenmektedir. Buna SCI-E ile birlikte SSCI'de ve AHCI'de dizinlenen toplam 588 dergi de eklendiğinde bu oran \%65'e (6833 dergi) yükselmektedir. ${ }^{13}$

\footnotetext{
${ }^{13}$ Toplam 10.465 derginin \%89,3’ü (9341) sadece bir dizinde (SCI: 6245, SSCI: 1711, AHCI 1385), \%8,7’si (907 dergi) en az iki dizinde (SCI+SSCI: 541, SSCI+AHCI: 355, SCI+AHCI: 35), binde üçü (38 dergi) üç dizinde de dizinlenmektedir. JCR'de MEP değerleri henüz verilmeyen ama WoS'ta dizinlenen dergi sayısı ise 179'dur $(\% 1,7)$.
} 
$\mathrm{Bu}$ alanlarda yayımlanan dergilerin MEP değerleri o dergilerde yayımlanan makalelere yapılacak ödeme miktarlarını da belirlemektedir. Tablo 3'te 2019 UBYT dergi listesi temel alınarak fen bilimleri, sosyal bilimler ve sanat ve insani bilimler dergilerine yapılan ödemelerin sayıları ve bu dergilere verilen destek miktarları, Şekil 3'te ise ilgili alanlardaki dergi sayıları, ödeme miktarları ve Tablo 3'teki istatistiklere dayanan kutu grafiği verilmektedir. Çeyreklik değerler dikkate alındığında en düşük ödeme yapılan ilk \%25'lik dilimde fen bilimleri dergilerine sosyal bilimler ve sanat ve insani bilimler dergilerinden $\% 9$ daha fazla ödeme yapılmaktadır. Benzeri bir biçimde fen bilimleri dergilerine yapılan ödemelerin ortancası (\%50’lik dilim) sosyal bilimler dergilerininkinden \%12, sanat ve insan bilimlerininkinden \%68 daha yüksektir. Sosyal bilimler dergilerinin ortancası da sanat ve insan bilimleri dergilerininkinden $\% 51$ daha yüksektir. Bu farklılıklar genel ortalamalara da yansımaktadır: Fen bilimleri dergilerine sosyal bilimlerinkinden \%9, sanat ve insan bilimlerininkinden \%108 daha yüksek ödeme yapılmaktadır. Sosyal bilimler dergilerine sanat ve insan bilimleri dergilerininkinin neredeyse ortalama bir katı (\%90) daha fazla ödeme yapılmaktadır. MEP değerleri nispeten daha yüksek olan $\% 75^{\prime}$ lik dilime gelindiğinde ise fen bilimleri ile sanat ve insan bilimleri ve sosyal bilimlerle sanat ve insan bilimleri dergilerine yapılan ödeme miktarları arasındaki fark daha da açılmaktadır (sırasıyla \%170 ve \%147).

\section{Tablo 3}

Alanlara göre dergilere yapılan ödemelerin karşılaştırılması

\begin{tabular}{|c|c|c|c|c|c|c|}
\hline \multirow[b]{2}{*}{$\begin{array}{l}\text { Tanımlayıcı } \\
\text { istatistikler }\end{array}$} & \multicolumn{3}{|c|}{ Ödeme miktarı (TL) } & \multicolumn{3}{|c|}{ Karş1laştırma } \\
\hline & SCI-E & SSCI & $\mathrm{AHCI}$ & $\begin{array}{l}\text { SCI-E - } \\
\text { SSCI }(\%)\end{array}$ & $\begin{array}{c}\text { SCI-E - } \\
\text { AHCI (\%) }\end{array}$ & $\begin{array}{c}\mathrm{SSCI}- \\
\mathrm{AHCI}(\%)\end{array}$ \\
\hline Minimum & 500 & 500 & 2000 & 0 & -75 & -75 \\
\hline Yüzde 25 & 2185 & 2000 & 2000 & 9 & 9 & 0 \\
\hline Ortanca & 3365 & 3018 & 2000 & 12 & 68 & 51 \\
\hline Ortalama & 4365 & 3991 & 2097 & 9 & 108 & 90 \\
\hline Yüzde 75 & 5400 & 4930 & 2000 & 10 & 170 & 147 \\
\hline Maksimum & 15000 & 15000 & 7500 & 0 & 100 & 100 \\
\hline
\end{tabular}

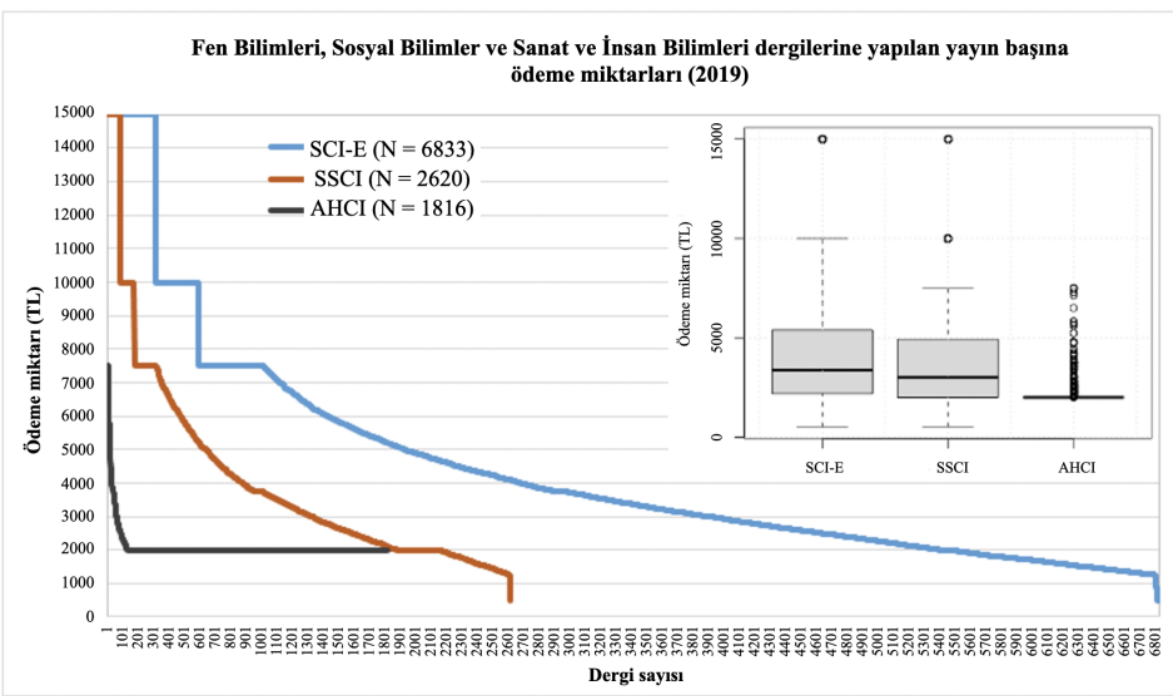

Şekil 3. Fen bilimleri, sosyal bilimler ve sanat ve insan bilimleri dergilerine yapılan ödeme miktarları. Not: Veriler 2019 y1lı UBYT dergi listesine dayanmaktadır. 
Dergilerin MEP değerlerinin çarpık olmasının yanı sıra dergilerde yayımlanan makalelere yapılan atıfların dağılımı da çarpıktır. WoS'ta listelenen makalelerin \%9-\%10'u bütün atıfların \%44'ünü toplamaktadır (Albarrán ve diğerleri, 2011). Aynı durum tek tek dergiler için de geçerlidir. Bir dergide yayımlanan az sayıdaki makale yüksek sayıda atıf alırken, çoğu makale ya çok düşük sayıda atıf almakta ya da hiç atıf almamaktadır. Hatta bu durum etki faktörleri oldukça yüksek olan dergiler için de geçerlidir. Bu dergilerde yayımlanan makalelerin yaklaşık dörtte üçü dergi etki faktörünün karşılığı kadar atıf alamamaktadır (Larivière ve diğerleri, 2016, Tablo 1). Dergilerin etki faktörüyle o dergilerde yayımlanan makalelerin aldıkları atıf sayıları arasında pozitif bir ilişki yoktur (Zhang, Rousseau ve Sivertsen, 2017). Aynı durum dergi etki faktörüne dayanan MEP değerleri için de geçerlidir. Fen bilimlerinde ve sosyal bilimlerde farklı konulardaki dergilerin atıf örüntüleri birbirinden oldukça farklıdır. Örneğin, sosyal bilimlerde kitap halen başat yayın türü iken fen bilimlerinde dergi makalesi son derecede yaygindır.

$\mathrm{Bu}$ durum, dergilere ait dergi etki faktörü ve MEP değeri gibi bibliyometrik ölçevlere dayanarak tek tek makalelerin etkisini ölçmenin pek isabetli olmadığını göstermektedir. Başka bir deyişle, makalelere verilen destek miktarını çarpık MEP değerleri dağılımlarının ortalamasına göre saptamak yanıltıcıdır. Şekil 3'teki veriler yeni destek algoritması oluşturulurken bu noktaların yeterince dikkate alınmadığını göstermektedir. Kaldı ki, daha önce de belirtildiği gibi, TÜBİTAK tarafından desteklenen dergilerde yayımlanan makaleler desteklenmeyen dergilerde yayımlananlardan daha yüksek sayıda atıf almamaktadır (Tonta ve Akbulut, 2020a).

Daha da önemlisi TR adresli yayınların fen bilimleri, sosyal bilimler ve sanat ve insani bilimlere göre dağılımı yukarıdaki dağılımlardan çok farklıdır. Örneğin, 2006-2015 yıllarında yayımlanan TR adresli makalelerin \%90'1 SCI-E'de, \%9'u SSCI'de, \%1'inden azı ise AHCI'de dizinlenen dergilerde yayımlanmıştır (Tonta ve Akbulut, 2019, s. 1957). Aşağıdaki karşılaşıtırmada da görüleceği gibi bu oranlar UBYT Programına göre 2015 ve 2019 yıllarında destek verilen makalelere de aynı şekilde yansımaktadır.

Öte yandan MEP değeri olmadığı için JCR'de listelenmeyen ve AHCI'de dizinlenen 1603 dergide yayımlanan makalelere, MEP değerleri 0,4 varsayılarak sabit bir ücret ödenmektedir (2000 lira, maksimum ödeme miktarının \%13'ü). Oysaki SSCI ve SCI-E'de de dizinlenen 213 AHCI dergisinin MEP değerlerinin ortancası $0,435^{\prime}$ tir. ${ }^{14}$ Başka bir deyişle, AHCI dergilerinin yarısından fazlası 2000 liranın üzerinde desteği hak etmektedir.

\section{Desteklenen Yayınlara Göre UBYT Programının Eski ve Yeni Destek Algoritmalarının Karşılaştırılması}

Bir önceki kısımda eski ve yeni destek algoritmaları 2015 ve 2019 yıllarında desteklenen dergi listelerine göre karşılaştırılmıştı. Bu kısımda ise benzeri bir karşılaştırma desteklenen yayınlar temel alınarak yapılmaktadır. Bu amaçla 2015 yılında desteklendiğini bildiğimiz yayınların 2019 y1lında uygulanmaya başlanan yeni algoritmaya göre desteklenip desteklenmediği ve desteklendiği takdirde bu yayınlara yapılacak ödeme miktarları karşılaştırılmaktadır. Bu karşılaşıtırmada $2015^{\prime}$ te desteklenen yayınların 2019 'da da aynı dergilerde yayımlanmış

\footnotetext{
${ }^{14}$ MEP değerleri olmayan ama JCR'de Q1 ve Q2 dergileri arasında listelenen sırasıyla üç ve dört AHCI dergisine 7500 'er ve 3750 'şer lira ödenmektedir.
} 
olduğu, bu dergilerin MEP değerlerinde genelde ufak bir artış (Fischer ve Steiger, 2018) olsa da aradan geçen sürede çok büyük değişiklikler göstermediği ve dolayısıyla ödeme miktarlarının pek değişmediği varsayılmaktadır.

Her ne kadar 2015 yılında 7500 lira olan maksimum destek miktarı 2019 y1lında 15.000 liraya yükseltilmiş olsa da 2015 yılının 7500 lirası 2019 y1lı cari fiyatlarıyla 15.028 liraya karşılık gelmektedir. ${ }^{15}$ Başka bir deyişle 2019' da ödeme miktarları bir kat artmış gözükmesine karşın aslında 2019 cari fiyatlarıyla bile 2015 yılına göre reel olarak artmamış, hatta \%0,19 (yaklaşık binde iki) oranında azalmıştır.

2015 y1lında 3031 dergide yayımlanan toplam 9715 TR adresli yayın desteklenmişti. ${ }^{16}$ Şekil 4'te 9715 yayına 2015 ve/veya 2019 yıllarında yapılan ödeme miktarları gösterilmektedir. Desteklenen yayınlar TR adresli yayınların yer aldığı dergilerin 2015 yılındaki MEP değerlerine ve bu değerlerin karşılığı olarak 2019 yılında bir yayına yapılması gereken tam ödeme miktarına (turuncu noktalar) göre sıralanmıştır. Aynı yayınlara 2015'te yapılan tam ödeme miktarları ise mavi noktalarla gösterilmektedir. Şeklin ilk kısmında dergi MEP değerleri olan ve hem 2015 hem de 2019'da ödeme yapılan 7251 yayın yer almaktadır. Daha sonra ise dergi MEP değerleri olan ve fakat 2015 algoritmasına göre desteklenip yeni algoritmaya göre desteklenmeyen 2158 yayın bulunmaktadır (7252-9409 numaralı yayınlar). Şeklin en sağında yer alan toplam 306 yayının MEP değerleri olmamasına karşın bu yayınlara 18'i Q1, 59'u Q2, 164'ü AHCI, 65'i ise TR adresli dergilerde yayımlandığ söz konusudur (ödeme miktarları sırasıyla 7500, 3750, 2000 ve 500 liradır).

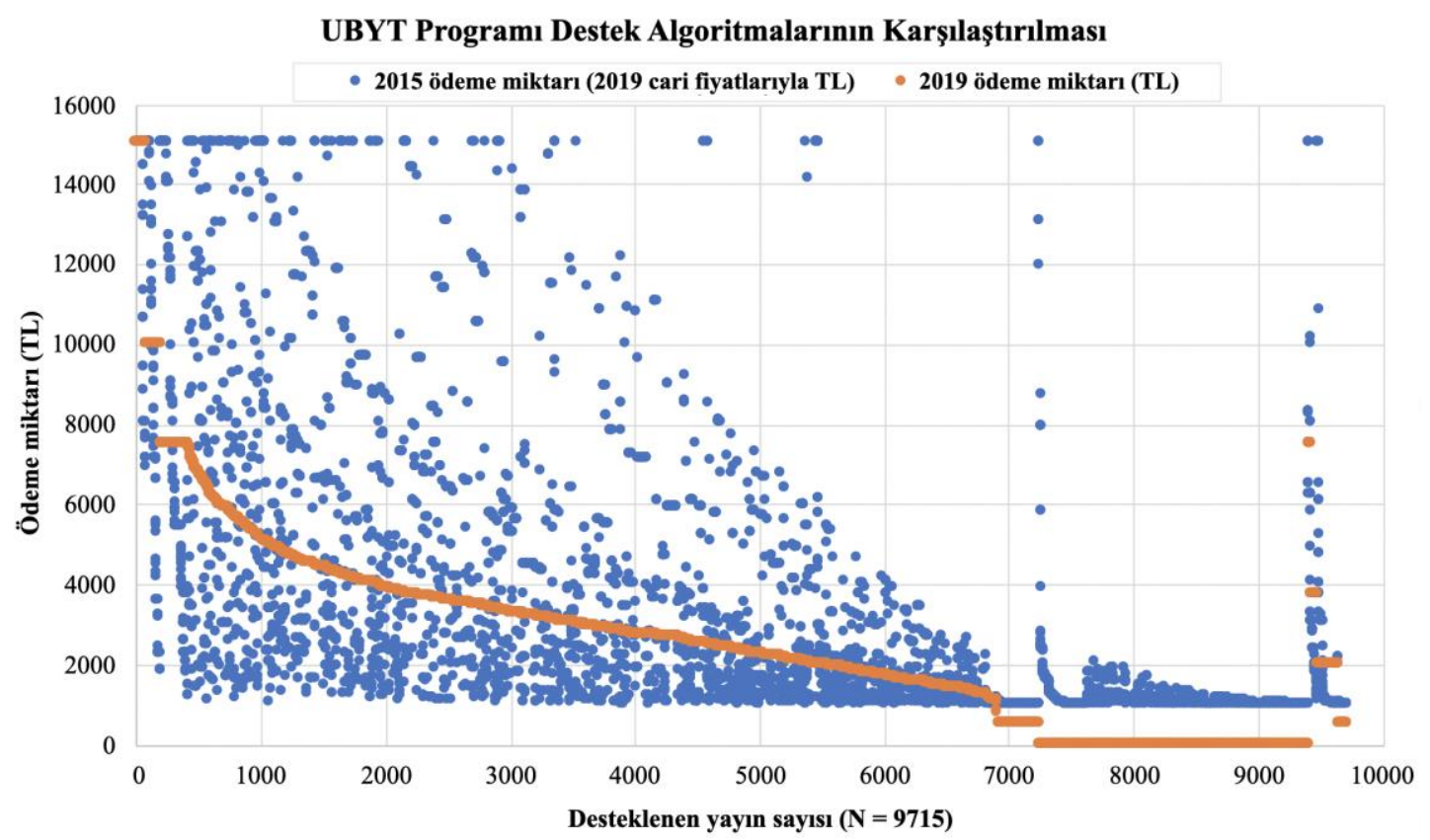

Şekil 4. UBYT Programı eski ve yeni destek algoritmalarının yayınlara yapılan ödeme miktarlarına göre karşılaştırılması

\footnotetext{
${ }^{15}$ Deflatör katsayıs1 2,0036976422. Bkz. 2019-2021 Dönemi (2018).

${ }^{16}$ Tablo 1'de 2015'te desteklenen yayın sayısı ULAKBIM'in faaliyet raporuna dayanarak 9260 olarak verilmişti (TÜBİTAK 2015b, s. 13). Ödeme verilerinde ise bu sayı 9715 'tir. Buradaki farkın sebebi ödeme veri setinin yayın yılı 2015 olan ve desteklenen çalışmaları içermesidir. Ancak yayın yılı 2015 olup destek ödemeleri 2016 yılında yapılan yayınlar olabilmektedir.
} 
2015'te desteklenen yayınların \%22,2'si (2158 yayın) yeni destek algoritmasına göre desteklenmemektedir. Yayın başına tam ödeme miktarı temel olarak alındığında TR adresli yayınlara yapılan ödeme miktarı 2015'te 35,2 milyon lira, 2019'da ise 25,3 milyon liraya karşılık gelmektedir. Ancak ortak yazarlı yayınlarda her zaman bütün ortak yazarlar destek için başvurmadıklarından 2015 'te yapılan gerçek ödemeleri dikkate almak gerekir. Buna göre 2015 'te TR adresli yayınların yazarlarına toplam 24,8 milyon lira ödenmiştir. Yeni algoritmaya göre bu yayınlara 2019' da 17,6 milyon lira ödenmesi söz konusudur (\%29 daha düşük).

Şekil 4'te dikkat çeken en önemli noktalardan birisi, aynı MEP değerine sahip dergilerde yayımlanan yayınlara 2015 ve 2019 yıllarında yapılan ödeme miktarlarının birbirinden çok farklı olmasıdır. Nitekim 2015'te MEP değerleri olan 2748 derginin dergi nihai puanlarıyla MEP değerleri arasındaki korelasyon katsayısı (Pearson's $r=0,52$, etki değeri $r^{2}=0,27$ ) yüksek değildir (Şekil 5). Başka bir deyişle, korelasyon katsayısı eski algoritmada dergilerin MEP değerlerine dayanarak hesaplanan DNP'leri her dört dergiden üçünün gerçek MEP değerlerini yansıtmamaktadır. Bunun başlıca nedenleri daha önce de değindiğimiz gibi eski algoritmada dergi MEP değerlerinin DNP'ye dönüştürülmesi için kullanılan algoritmanın işleyişi ve az sayıda dergisi olan konu gruplarının diğer konu gruplarıyla birleştirilmesidir. Şekil 5'teki bulgular daha önceki benzeri bulguları desteklemektedir (bkz. Tonta, 2017b, 5. Bölüm).

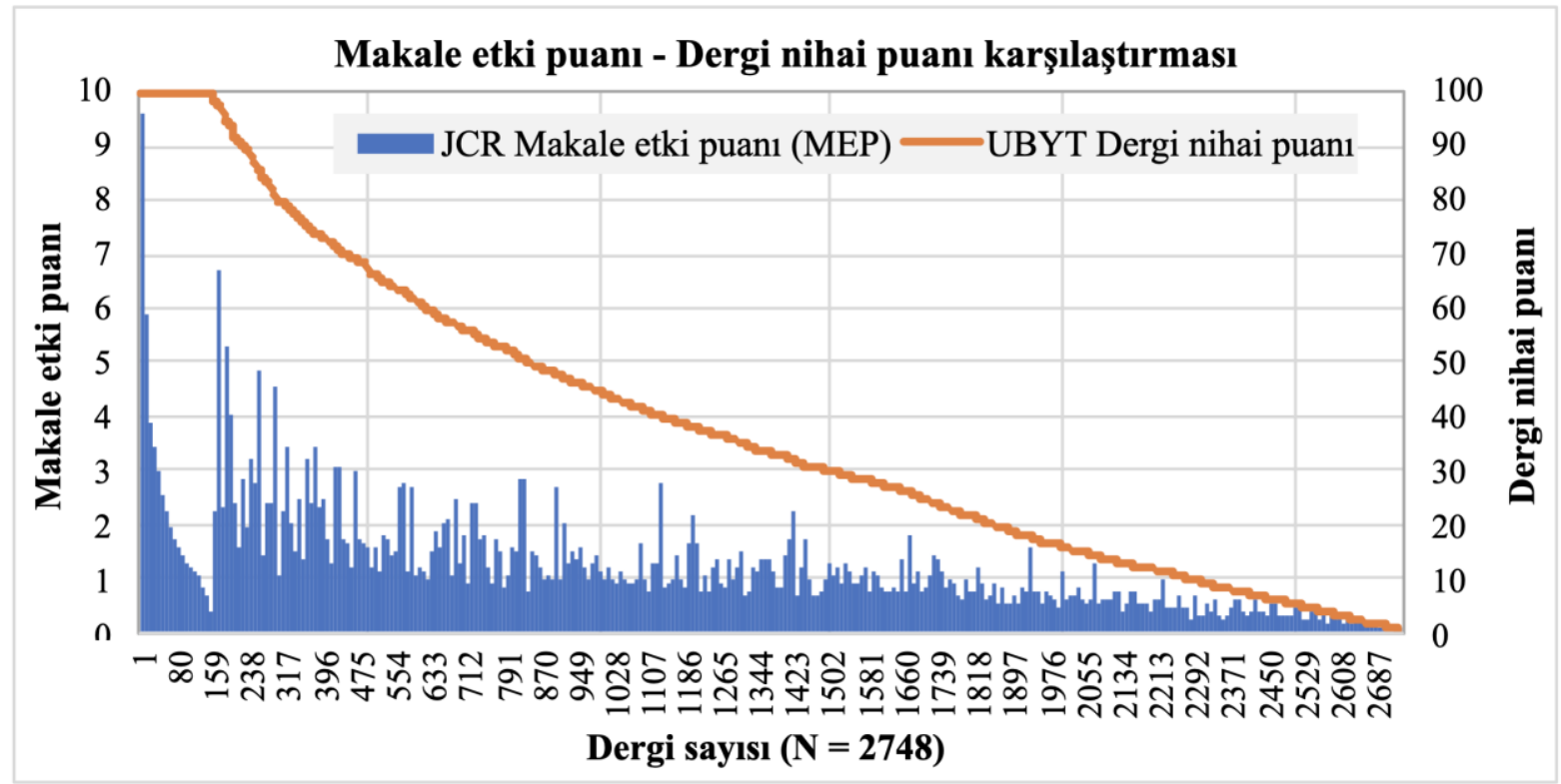

Şekil 5. Dergilerin dergi nihai puanlarıyla makale etki puanlarının karşılaştırılması

Not. Okumayı kolaylaştırmak için MEP değeri 10'dan büyük olan dört yayın gösterilmemiştir.

Aşağıda 2015 yılında MEP değerleri olan ve dergi nihai puanına göre desteklenen 7251 yayına yapılan ödemelerle bu ödemelerin 2019 yilında yeni destek algoritmasında kullanılan MEP değerlerine göre karşılıkları yayınların 0,25'lik MEP değeri dilimlerine göre karşılaştırılmaktadır (Tablo 4 ve Şekil 6). ${ }^{17}$ Tablo 5'te ise ödemelerle ilgili tanımlayıcı istatistikler sunulmaktadır.

UBYT Programı çerçevesinde MEP değeri olan dergilerde yapılan yayınlara 2015'te yaklaşık 22 milyon lira destek verilmiştir. 2019'da ise aynı yayınlar yeni algoritmaya göre 17 milyon lira desteği hak etmektedir. Destek miktarının yaklaşık üçte biri her iki yılda da MEP

\footnotetext{
${ }^{17}$ MEP değeri olmayan 1787 dergide çıkan ve desteklenen TR adresli yayınlar karşılaştırmaya dâhil edilmemiştir.
} 
değerleri 0,5 ile 0,75 arasındaki dergilerde çıkan yayınlara harcanmıştır. Desteklenen yayınların 2015'te \%78'inin, 2019'da ise \%75'inin MEP değerleri dünya ortalamasının (1,000) altındadır. Desteklenen yayınların MEP değerlerinin ortancası 0,592'dir.

Toplam ödeme miktarı 2015'e oranla 2019'da ortalama \%23 düşmüştür. Bunun temel nedeni 2019' da başlatılan MEP eşik değeri uygulamasıdır. Yeni algoritmaya göre MEP değeri ortancanın altında olan dergilere 2015 yılına oranla daha yüksek, ortancanın üzerinde olan dergilere ise daha düşük ödeme yapılması söz konusudur. Bu bulgular eski algoritmada dergilerin MEP değerlerinin DNP'ye dönüştürülürken değişime uğradığını, formül 1'deki üs alma işlemi nedeniyle DNP'si nispeten daha yüksek yayınlara daha yüksek ödeme yapıldığını göstermektedir. Ancak desteklenen yayınların çok küçük bir yüzdesi formüldeki üs alma işleminin avantajlarından yararlanabilmiştir. Çünkü MEP değeri nispeten daha yüksek dergilerde yayımlanan TR adresli makalelerin oranı oldukça düşüktür. Örneğin, maksimum ödeme miktarının (15.000 lira) yarısını hak eden TR adresli yayınların oranı sadece \%10'dur (2015'te \%8, 2019'da \%10).

\section{Tablo 4}

Destek miktarlarının makale etki puanlarına göre dă̆glımı

\begin{tabular}{|c|c|c|c|c|c|}
\hline \multirow[b]{2}{*}{$\begin{array}{l}\text { Makale etki } \\
\text { puanı (MEP) }\end{array}$} & \multirow[b]{2}{*}{$\begin{array}{l}\text { Desteklenen } \\
\text { yayın sayısı }\end{array}$} & \multicolumn{2}{|l|}{2015} & \multicolumn{2}{|l|}{2019} \\
\hline & & $\begin{array}{l}\text { Ödeme } \\
\text { miktarı TL) }\end{array}$ & $\begin{array}{l}\text { Yüzde } \\
(\%)\end{array}$ & $\begin{array}{l}\text { Ödeme } \\
\text { miktarı TL) }\end{array}$ & $\begin{array}{l}\text { Yüzde } \\
(\%)\end{array}$ \\
\hline $0-0,25$ & 556 & 580438 & 3 & 431388 & 3 \\
\hline $0,25-0,5$ & 2111 & 3648677 & 17 & 3188505 & 19 \\
\hline $0,5-0,75$ & 2358 & 7848973 & 36 & 5448432 & 32 \\
\hline $0,75-1$ & 1141 & 4946477 & 22 & 3500503 & 21 \\
\hline $1-1,25$ & 487 & 2262003 & 10 & 1761391 & 10 \\
\hline $1,25-1,5$ & 184 & 917164 & 4 & 782486 & 5 \\
\hline $1,50-1,75$ & 187 & 863693 & 4 & 791108 & 5 \\
\hline $1,75-2$ & 33 & 150959 & 1 & 110908 & 1 \\
\hline $2-2,25$ & 49 & 177022 & 1 & 241379 & 1 \\
\hline $2,25-2,5$ & 39 & 234334 & 1 & 206982 & 1 \\
\hline $2,5-2,75$ & 13 & 57381 & 0 & 55492 & 0 \\
\hline $2,75-3$ & 16 & 45803 & 0 & 62662 & 0 \\
\hline$>=3$ & 77 & 322853 & 1 & 359616 & 2 \\
\hline Toplam & 7251 & 22055778 & 100 & 16940853 & 100 \\
\hline
\end{tabular}

Şekil 6, toplam ödeme miktarının yayınların MEP değerlerine göre dağılımı açısından iki destek algoritması arasında pek fark olmadığını göstermektedir. Ancak toplam ödeme miktarının MEP değeri aralıklarına dağılım oranları arasında büyük fark olmaması eski ve yeni algoritmaların işleyiş biçimlerinin de aynı olduğu anlamına gelmemektedir. Dergi bazında TR adresli yayınlara 2015 ve 2019 yıllarında yapılan ödeme miktarlarının birbirinden çok farklı olduğu ve DNP ve MEP değerleri arasında güçlü bir korelasyon olmadığı daha önce gösterilmişti (Şekil 4 ve Şekil 5). Bu durum yayın bazındaki ödeme miktarları için de geçerlidir. Tablo 6'da 2015'te tam DNP'si (100) olan ve maksimum destek verilen 156 yayının MEP değerleri (minimum 0,409, maksimum 22,142) ve bu yayınlara yapılan ödeme miktarları 
(minimum 2045, maksimum 15.000 lira) karşış̧ıırılmaktadır. Başka bir deyişle eski algoritmaya göre maksimum miktarda ödeme yapılan bazı yayınlara yeni algoritmaya göre bu miktarın \%14'ü kadar ödeme yapılabilmektedir. Bu durum eski destek algoritmasında farklı JCR konuları altında listelenen dergilerin MEP değerlerinin DNP'ye dönüştürülmesi sırasında geçirdiği değişimin başka bir göstergesidir. Örneğin, Proceedings of the National Academy of Sciences of USA (PNAS, MEP: 4,878) dergisi dünyanın en saygın dergilerinden birisidir. Bu derginin nihai puanı eski algoritmaya göre 86,03 puana karşılık gelmekteydi. Bu durum $P N A S$ 'ta yayımlanan makalelere MEP değerleri $P N A S$ ' 1 onda biri kadar olan dergilerde yayımlanan ama farklı konular altında listelendikleri için DNP'si daha yüksek olan makalelere ödenen miktarın ancak üçte ikisi kadar ödeme yapılmasına yol açmaktaydı.

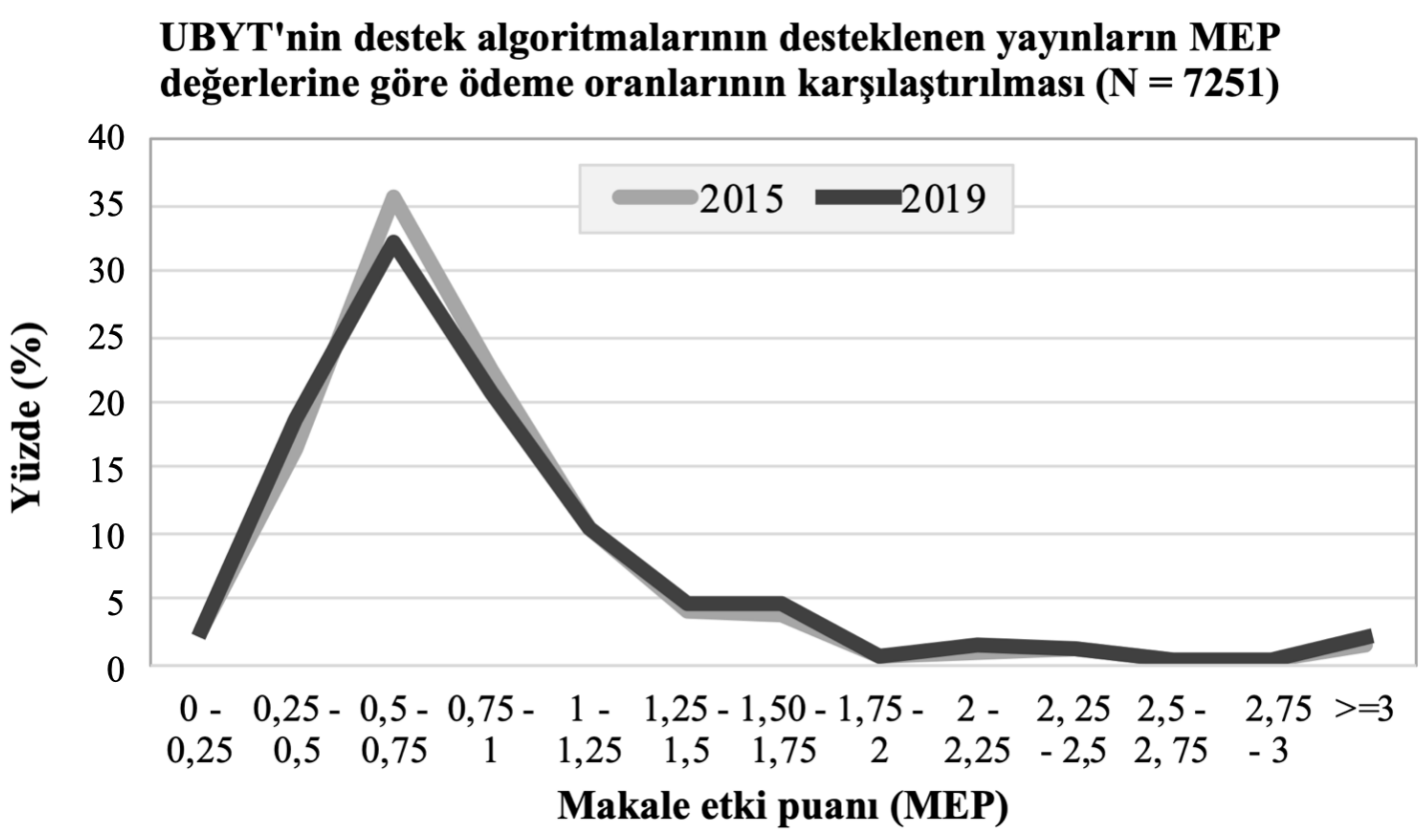

Şekil 6. Destek miktarlarının makale etki puanlarına göre dağılımı

\section{Tablo 5}

2015 ve 2019 ödemeleriyle ilgili tanımlayıcı istatistikler

\begin{tabular}{lcrrr}
\hline & $\begin{array}{c}2015 \\
\text { Makale }\end{array}$ & \multicolumn{3}{c}{ Miktar (TL) } \\
\cline { 3 - 5 } Tanımlayıc1 & $\begin{array}{c}\text { etki puanı } \\
\text { (MEP) }\end{array}$ & $\begin{array}{c}2015(2019 \\
\text { cari } \\
\text { fiyatlatistikler }\end{array}$ & 2019 & $\begin{array}{c}\text { Artma / } \\
\text { Azalma } \\
(\%)\end{array}$ \\
\hline Minimum & 0,004 & 501 & 250 & -50 \\
Yüzde 25 & 0,399 & 1057 & 1265 & 20 \\
Ortanca & 0,592 & 1827 & 2000 & 9 \\
Ortalama & 0,704 & 3042 & 2336 & -23 \\
Yüzde 75 & 0,816 & 3810 & 3071 & -19 \\
Maksimum & 22,412 & 15028 & 15000 & 0 \\
Toplam & & 22055778 & 16940853 & -23 \\
\hline
\end{tabular}

Not. Yeni algoritmaya göre 2019 yılında 10 ve daha fazla ortak yazarı olan yayınlarda yazar başına ödeme miktarı hesaplanırken sadece TR adresli yazarlar dikkate alınmaktadır. Bu özelliğe sahip 93 yayın vardır. 
Tablo 6

\begin{tabular}{|c|c|c|c|}
\hline $\begin{array}{l}\text { Tanımlayıcı } \\
\text { istatistikler }\end{array}$ & $\begin{array}{l}2015 \\
\text { MEP } \\
\text { değeri }\end{array}$ & $\begin{array}{l}2019 \text { ödeme } \\
\text { miktarı (TL) }\end{array}$ & $\begin{array}{l}2015 \text { ödeme } \\
\text { miktarı (2019 cari } \\
\text { fiyatlariyla TL) }\end{array}$ \\
\hline Minimum & 0,409 & 2045 & 15028 \\
\hline Yüzde 25 & 1,156 & 5780 & 15028 \\
\hline Ortanca & 1,669 & 7500 & 15028 \\
\hline Ortalama & 2,624 & 8722 & 15028 \\
\hline Yüzde 75 & 2,954 & 10000 & 15028 \\
\hline Maksimum & 22,412 & 15000 & 15028 \\
\hline
\end{tabular}

Fen bilimleri ve sosyal bilimler yayınlarının MEP değerleri ve dolayısıyla bu yayınlara yapılan ödeme tutarları da birbirinden oldukça farklıdır. Tablo 7'de MEP değeri olan dergilerde yayımlanan ve desteklenen 7251 yayının 2015 ve 2019 yıllarında listelendikleri atıf dizinlerine göre dağılımı verilmektedir. SSCI yayınlarının sayısı SCI-E yayınlarının sayısının yaklaşık \%9'u kadardır. Yayınların \%86's1 sadece SCI-E'de, \%8'i sadece SSCI'de, \%5'i ise her iki dizinde de dizinlenmektedir. SCI-E ya da SSCI dizinlerinde de dizinlenen AHCI yayınlarının oranı ise sadece \%1'dir. Sadece SCI-E'de dizinlenen yayınlara yapılan ödemeler toplam ödemelerin \%86-\%87'sini oluşturmaktadır. Oysaki sadece SSCI'de dizinlenen ve toplam yayınların \%8'ini oluşturan yayınlar toplam ödeme miktarından aynı ölçüde yararlanamamaktadır (\%5-\%6). Başka bir deyişle SSCI'de dizinlenen yayınlara SCI-E'de dizinlenen yayınlara ödenen miktardan yaklaşı \%38 (2015) ile \%25 (2019) daha az ödeme yapılmaktadır. Her ikisinde de dizinlenen yayınlar için bu fark ortadan kalkmaktadır.

Yeni algoritmaya göre 2019 yılında SCI-E, SSCI ve AHCI'de dizinlenen yayınlara yapılan ve Tablo 7'de verilen ödemelerin ortanca ve ortalamaları arasındaki farkların oranı Şekil 7'de gösterilmektedir. ${ }^{18}$ MEP değerleri olmamasına rağmen AHCI yayınlarına 2000 lira sabit ücret ödendiğinden AHCI yayınlarına yapılan ödeme miktarları da Şekil 7'ye yansıtılmıştır. Desteklenen SCI-E yayınlarına yapılan ödemeler SSCI yayınlarından ortalama $\% 28$ (ortanca \%40), ${ }^{19}$ AHCI yayınlarından ortalama \%119 (ortanca \%103) daha yüksektir. Benzeri bir biçimde SSCI yayınlarına AHCI yayınlarından ortalama \%93 (ortanca \%74) daha yüksek ödeme yapılmaktadır.

Bilindiği gibi JCR belli bir alandaki dergileri etki faktörlerine göre sıralamakta ve sıralamada en üstteki \%25'lik dilimdeki dergileri Q1, ikinci, üçüncü ve dördüncü \%25'lik dilimlerdeki dergileri sırasıyla Q2, Q3 ve Q4 dergileri olarak adlandırmaktadır. Bazı dergiler birden fazla konu altında listelendiğinden farklı çeyreklik dilimlerde yer alabilmektedir. Dergi çeyreklik dilimleri JCR'de listelenen 255 konunun her biri için ayrı ayrı hesaplandığından farklı konulardaki Q1 ya da Q2 dergilerinin etki faktörleri de birbirinden farklıdır. Bu durum farklı

\footnotetext{
18 2019'da SCI-E'de dizinlenen ve MEP değerleri 0,250'den düşük olan 332 (111 Q3 ve 211 Q4), SSCI'de dizinlenen ve tümü Q4 dergilerinde yayımlanan MEP değerleri 0,100'den düşük olan 283 yayın olmak üzere toplam 615 yayın desteklenmektedir. Bu yayınların tamamı Türkiye'de yayımlanan dergilerde çıkmıştır. Tablo 7'de \%25'lik dilimdeki SCI-E ve SSCI'de dizinlenen yayınlara yapılan ödeme miktarları (sırasıyla 500 lira ve 1320 lira) arasındaki \%164'lük farkın nedeni budur. Başka bir deyişle SCI-E ve SSCI dergileri için farklı eşik değerleri olması nedeniyle $\% 25^{\prime}$ 'lik dilimdeki fark diğer dilimlerden daha yüksektir.

${ }^{19}$ Eski algoritmaya göre 2015 yılında SCI-E yayınlarına SSCI yayınlarından ortalama \%53 (ortanca \%76) daha yüksek ödeme yapılmıştır (yeni algoritmadaki oranların yaklaşık bir katı).
} 
konularda yayımlanan literatürün özelliklerinden kaynaklanmaktadır. Kimi disiplinlerde belli bir konuda yüzlerce dergi yayımlanırken kimilerinde bu sayı 20'den azdır. Kimi alanlarda çok sayıda araştırmacı varken kimi alanlarda araştırmacı sayısı sınırlıdır. Farklı disiplinlerin yayın yapma örüntüleri (tür, yayın ve atıf sayısı, yayın sıklığı vs.) de birbirinden farklıdır.

\section{Tablo 7}

Alanlara göre yayınlara yapılan ödemelerin karşılaştırılması

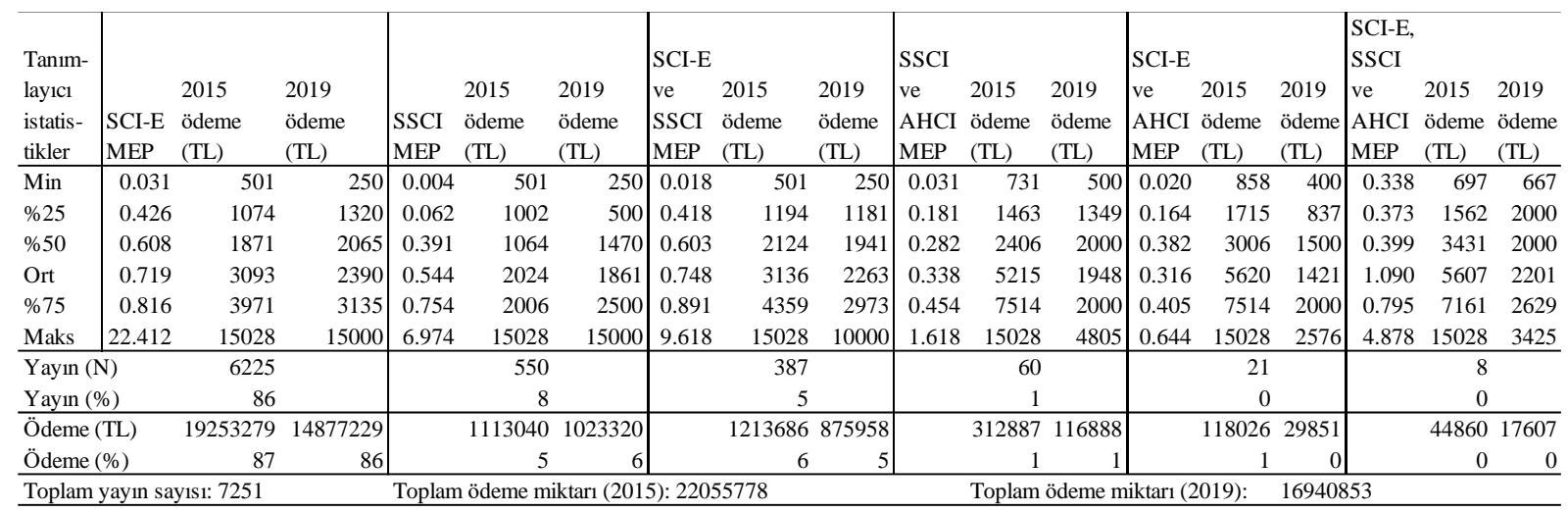

Not. "SCI-E": Science Citation Index Expanded; "SSCI": Social Science Citation Index; "AHCI": "Arts \& Humanities Citation Index; "MEP": Makale etki puanı; "Min": Minimum; "Maks": Maksimum; "050": Ortanca; "Ort": Aritmetik ortalama. Sadece AHCI'de dizinlenen yayınların MEP değerleri olmadığından tabloya dâhil edilmemiştir. 2015 ödeme miktarları 2019 cari fiyatlarıyla hesaplanmıştır. 2019 yılı toplam ödeme yüzdesi yuvarlama nedeniyle $\% 100$ 'den farklıdır.

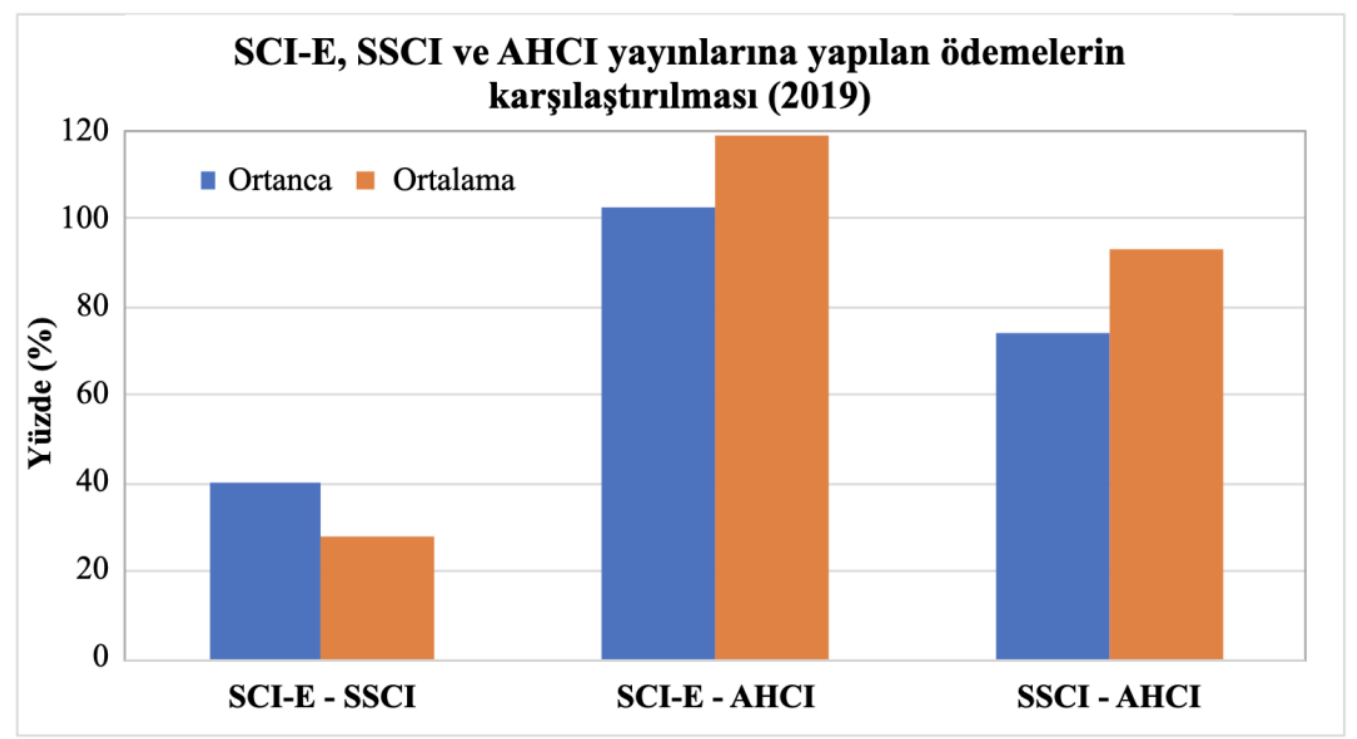

Şekil 7. Alanlara göre yayınlara yapılan ödemelerin ortanca ve ortalamaları

Tablo 8'de 7251 TR adresli yayının 2015 ve 2019 yıllarında JCR'de hangi çeyreklik dilimlerdeki dergilerde yayımlandığını göstermektedir. ${ }^{20}$ Desteklenen yayınların yarısı Q1, \%28'i Q2, \%12'si Q3 ve \%9'u Q4 dergilerinde yayımlanmıştır. Toplam destek miktarının 2015'te \%91'i, 2019'da \%88'i “yüksek etkili dergiler” olarak nitelendirilen Q1 ve Q2 dergilerinde çıkan TR adresli yayınları desteklemek için kullanılmıştır. 2019'da Q1 ve Q2 dergilerinde yayımlanan ve desteklenen TR adresli yayınların yaklaşık \%90'1 SCI-E, \%5'i SSCI, \%5'i her iki dizinde de listelenmektedir. Q3 ve Q4 dergilerinde yayımlananlar için bu

\footnotetext{
${ }^{20}$ Birden fazla konu altında çeyreklik dilimi hesaplanan yayınların en yüksek çeyreklik dilimi dikkate alınmıştır.
} 
oranlar sırasıyla \%75, \%22 ve \%4'tür (yuvarlama nedeniyle toplam \%101'dir). Başka bir deyişle, Q3 ve Q4 dergilerinde yayımlanan ve desteklenen sosyal bilimler yayınlarının oranı Q1 ve Q2 dergilerine oranla yaklaşık dört kat daha fazladır.

\section{Tablo 8}

Dergi çeyreklik dilimlerine göre yayınların MEP değerlerinin ve ödeme miktarlarının karşılaştırılması

\begin{tabular}{|c|c|c|c|c|c|c|c|c|c|c|c|c|}
\hline $\begin{array}{l}\text { Tanım- } \\
\text { layıcı } \\
\text { istatis- } \\
\text { tikler }\end{array}$ & \begin{tabular}{|l} 
Q1 \\
MEP
\end{tabular} & $\begin{array}{l}2015 \\
\text { ödeme } \\
\text { (TL) }\end{array}$ & $\begin{array}{l}2019 \\
\text { ödeme } \\
\text { (TL) }\end{array}$ & $\begin{array}{l}\text { Q2 } \\
\text { MEP }\end{array}$ & $\begin{array}{l}2015 \\
\text { ödeme } \\
\text { (TL) }\end{array}$ & $\begin{array}{l}2019 \\
\text { ödeme } \\
\text { (TL) }\end{array}$ & $\begin{array}{l}\text { Q3 } \\
\text { MEP }\end{array}$ & $\begin{array}{l}2015 \\
\text { ödeme } \\
\text { (TL) }\end{array}$ & $\begin{array}{l}2019 \\
\text { ödeme } \\
\text { (TL) }\end{array}$ & Q4 & $\begin{array}{l}2015 \\
\text { ödeme } \\
(\mathrm{TL})\end{array}$ & $\begin{array}{l}2019 \\
\text { ödeme } \\
(\mathrm{TL})\end{array}$ \\
\hline Min & 0.255 & 501 & 253 & 0.152 & 502 & 188 & 0.059 & 501 & 250 & 0.004 & 501 & 250 \\
\hline$\% 25$ & 0.595 & 1710 & 1667 & 0.399 & 1065 & 1298 & 0.284 & 763 & 1070 & 0.062 & 731 & 500 \\
\hline$\% 50$ & 0.752 & 3143 & 2695 & 0.517 & 1579 & 1913 & 0.348 & 1060 & 1455 & 0.083 & 1008 & 535 \\
\hline Ort & 0.960 & 4346 & 2931 & 0.559 & 2085 & 2061 & 0.386 & 1415 & 1580 & 0.172 & 1041 & 942 \\
\hline$\% 75$ & 1.018 & 5827 & 3750 & 0.653 & 2425 & 2665 & 0.467 & 1493 & 1978 & 0.288 & 1054 & 1410 \\
\hline Maks & 22.412 & 15028 & 15000 & 2.741 & 15028 & 7500 & 1.082 & 15028 & 5395 & 0.889 & 15028 & 4445 \\
\hline \multicolumn{2}{|c|}{ Yayın $(\mathrm{N})$} & \multicolumn{2}{|l|}{3637} & \multicolumn{3}{|c|}{2062} & \multicolumn{3}{|c|}{895} & \multicolumn{3}{|c|}{657} \\
\hline \multicolumn{2}{|c|}{ Yayın $(\%)$} & 50 & & \multicolumn{3}{|c|}{28} & \multicolumn{3}{|c|}{12} & \multicolumn{3}{|c|}{9} \\
\hline \multicolumn{2}{|c|}{ Ödeme (TL) } & 15805639 & 10658904 & & 4299580 & 4248820 & & 1266758 & 1414145 & & 683800 & 618984 \\
\hline \multicolumn{2}{|c|}{ Ödeme (\%) } & 72 & 63 & & 19 & 25 & & 6 & 8 & & 3 & 4 \\
\hline
\end{tabular}

Toplam yayın sayısı: $7251 \quad$ Toplam ödeme miktarı (2015): 22055778 Toplam ödeme miktarı (2019): 16940853

Not: "MEP”: Makale etki puan1; "Min”: Minimum; "Maks": Maksimum; “\%50”: Ortanca; “Ort”: Aritmetik ortalama. Sadece AHCI'de dizinlenen yayınların MEP değerleri olmadığından tabloya dâhil edilmemiştir. 2015 ödeme miktarları 2019 cari fiyatlarıyla hesaplanmıştır. Toplam yayın yüzdesi yuvarlama nedeniyle \%100'den farklidir.

Etki değeri nispeten daha yüksek Q1 ve Q2 dergilerine yapılan yüksek ödeme yüzdeleri UBYT Programının başarısını ölçmek için de kullanılmaktadır. Örneğin, 2019 yılı ULAKBİM Faaliyet Raporu'nda JCR'de \%50'lik dilimde yer alan Q1 ve Q2 dergilerinde yayımlanan makalelere UBYT destek bütçesindeki toplam kaynağın \%86'sının aktarıldığı belirtilmektedir (TÜBİTAK 2019b, s. 66).

JCR verilerine dayanan bu yüzdeler doğru olmakla birlikte kanımızca resmin bütününü tam olarak yansıtmamaktadır. Disiplinler arasındaki farklara yukarıda kısaca değinmiştik. Fakat dergi çeyreklik dilimlerinin performans göstergesi olarak kullanılmasında göz önünde bulundurulması gereken başka noktalar da bulunmaktadır. Belli bir alanda yayımlanan dergiler çeyreklik dilimlere tanım gereği aşağı yukarı eşit olarak dağılmaktadır. Ancak yayınlar dergilere eşit olarak dağılmamaktadır (Liu, Guo ve Zuo, 2016; Liu, Hu ve Gu, 2018; Miranda ve Garcia-Carpintero 2019). Örneğin, 2015 yllındaki SCI-E'de dizinlenen 8500'ün üzerindeki dergide yayımlanan yaklaşı 1,3 milyon makalenin \%36'sı ile \%46'sı Q1, sadece \%13'ü ile \%17'si Q4 dergilerinde çıkmıştır (Liu ve diğerleri 2016). Nitekim, UBYT tarafından desteklenen yayınların yarısı Q1 dergilerinde yayımlanmıştır.

Bir diğer husus, yukarıdaki tablodaki dergilerin çeyreklik değerlerinden de kolayca görülebileceği gibi, Q2, Q3 ve Q4 yayınları arasında MEP değerleri Q1 yayınlarının minimum MEP değerinden daha yüksek olan binlerce yayın bulunmaktadır. ${ }^{21}$ Aslına bakılırsa destek için MEP eşik değeri 0,250 olduğundan desteklenen Q2 yayınlarının hemen hemen tamamının, Q3 yayınlarının \%83'ünün, Q4 yayınlarının üçte birinin MEP değerleri Q1 minimum MEP

$21 \mathrm{Bu}$ karşılaştırma dergilerin etki faktörleri yerine nispeten daha durağan olan MEP değerleri üzerinden yapılmıştır. 
değerinden daha yüksektir. Benzer bir ilişki Q2 yayınlarının minimum MEP değeriyle Q3 ve Q4 yayınları (sırasıyla \%92 ve \%41), Q3 yayınlarının minimum MEP değeriyle Q4 yayınları (\%98) için de geçerlidir. Dolayısıyla böyle bir karşılaştırma için belki de daha güvenilir bir yöntem dergilerin MEP değeri dünya ortalamasının $(1,000)$ üzerinde olan ve desteklenen yayın sayılarını ve oranlarını kullanmaktır. Desteklenen ve MEP değeri olan 7251 yayının sadece \%15'i (1086 yayın) MEP değeri bir ve üzerindeki dergilerde yayımlanmıştır. Bu oran Q1 dergileri için \%27 (983/3637), Q2 dergileri için \%5’tir (100/2062). Q3 dergilerinde MEP değeri birin üzerinde olan ve desteklenen sadece üç TR adresli yayın vardır.

Öte yandan dergilerin MEP değerleri ve dolayısıyla çeyreklik değerleri yükseldikçe bu dergilerde yayımlanan makalelere yapılan ödeme miktarları da göreceli olarak artmaktadır. Bu durum destek için başvuru yapmayı en azından bazı yazarlar için daha çekici hale getiriyor olabilir. Ayrıca ödeme miktarı yükseldikçe ortak yazarlı yayınlar için birden fazla yazarın destek için başvurma olasılığının da artması beklenmelidir. Çünkü ödeme miktarı arttıkça çok yazarlı yayınlarda yazar başına minimum ödeme miktarı (250 lira) kuralına takılmadan ortak yazarların başvuru yapabilme olasılıkları da yükselmektedir.

$\mathrm{Bu}$ açılardan değerlendirilecek olursa tek başına Q1 ve Q2 dergilerine yapılan ödemelerin toplam ödemeler içindeki payının yüksek olmasını bir performans göstergesi olarak kullanırken daha ihtiyatlı davranmakta yarar olduğunu söylemek mümkündür.

\section{Değerlendirme}

UBYT Programının eski ve yeni destek algoritmalarının uygulama usul ve esasları, desteklenen dergi listeleri ve desteklenen yayınlar açısından incelendiği bu araştırmadan elde edilen bulgular aşağıda kısaca değerlendirilmektedir.

Eski destek algoritmasında kullanılan dergi nihai puanı hesaplamasından vazgeçilerek yeni algoritmada yayınlara yapılan ödeme miktarlarını hesaplamak için doğrudan dergilerin MEP değerlerinin kullanılması olumlu bir gelişmedir. Çünkü gerek daha önceki araştırmalarda (örneğin, Tonta, 2017b) gerekse bu araştırmada dergilerin MEP değerlerini dergi nihai puanına dönüştürmek için kullanılan formülün istendiği gibi işlemediği ortaya çıkmıştır. DNP, desteklenen dergilerin dörtte üçünün gerçek MEP değerlerini yansıtmamaktadır. ${ }^{22}$

Yeni destek algoritması ile belirli MEP değeri aralıklarındaki yayınlara yapılan ödeme miktarlarının toplam ödeme miktarına oranları eski algoritmadakinden pek farklı değildir. MEP değeri dünya ortalamasının $(1,000)$ altında olan yayınlara verilen desteğin oranı da yeni destek algoritmasıyla pek değişmemiştir (\%78'den \%75'e düşmüştür) (Tablo 4). Ancak tek tek yayınlara yapılan ödemeler DNP yerine dergilerin JCR'de listelenen MEP değerlerine göre hesaplandığından daha tahmin edilebilir, saydam ve nispeten daha adil hale getirilmiştir. Ama yeni destek algoritmasında kullanılan dergi MEP değerlerinin daha önceki sorunları tamamıla çözdüğünü söylemek mümkün değildir. Çünkü dergilerin MEP değerlerinin dağılımının çarpık olması, bu değerlerin alanlara göre büyük farklılıklar göstermesi, AHCI'de dizinlenen dergilerin MEP değerlerinin hesaplanmaması vb. gibi sorunlar yeni algoritmadaki yaklaşımın da gözden geçirilmesini gerektirmektedir. Yeni algoritmada yayınların büyük bir çoğunluğu

${ }^{22}$ Dergi nihai puanının 2018 ve 2019 yıllarında Akademik Teşvik Ödeneği Yönetmeliğinde de kullanıldığı anlaşılmaktadır (Akademik, 2018). 
(\%92) için ödeme miktarının dergilerin belli bir süre içinde aldıkları atıf sayılarına dayanan MEP değerlerindeki artışlara göre doğrusal olarak artması ve AHCI dergilerinde yayımlanan makalelere tam ödemenin yaklaşık \%13'ü kadar (2000 lira) ödeme yapılmasına karar verilmesi bu sorunlar üzerinde yeterince durulmadığı izlenimi uyandırmaktadır. Nitekim sadece bir yıllık bir uygulamadan sonra desteklenecek dergiler için MEP eşik değerlerinin 2020'de yeniden düzenlenmesine gerek duyulmuştur (TÜBİTAK, 2020a).

MEP eşik değeri uygulaması eski algoritma ile desteklenen ve neredeyse desteklenen yayınların yarısını oluşturan ama minimum destek miktarını hak etmeyen (Tonta, 2017b, s. 64) yayınlara verilen desteği de sonlandırmıştır. Eşik değeri nedeniyle UBYT desteklenecek dergi listesindeki sayılar bir önceki yıla göre 2019' da \%19, 2020'de \%17 azalmıştır. Başka bir deyişle yeni algoritma ile eskiden desteklenen dergilerin üçte birine artık destek verilmemektedir. MEP eşik değeri uygulaması maksimum ödeme miktarı iki katına çıkmış olmasına karşın 2019'da toplam ödeme miktarını yaklaşık dörtte bir oranında azaltmaktadır. 2020 yılında SSCI-E dergileri için MEP eşik değeri 0,500'e yükseltildiği için daha da az sayıda yayının desteklenmesi beklenmektedir.

Ancak MEP eşik değeri uygulamasının fen bilimleri ve sosyal bilimler dergilerine etkileri birbirinden oldukça farklıdır. 2019 yılında desteklenen 6225 SCI-E ve 550 SSCI yayınının yarısının MEP değerleri sırasıyla 0,609 (2065 lira) ve 0,391'den (1470 lira) daha düşüktür. Genel olarak sosyal bilimler (SSCI) ile sanat ve insan bilimleri (AHCI) alanlarında yayımlanan makalelere yapılan ödeme miktarlarının, fen bilimlerininkiyle (SCI-E) karşılaştırıldığında pek hakkaniyetli olmadığı anlaşılmaktadır. AHCI dergileri için belirlenen ve maksimum ödeme miktarının sadece \%13'üne karşılık gelen oldukça mütevazı sabit ödeme miktarının (2000 lira) neye göre kararlaştırıldığı pek açık değildir. İşin ilginç yanı (bu araştırmanın esas konusu olmasa da) son Akademik Teşvik Ödeneği Yönetmeliğinde (2020) de AHCI dergileri Q3 dergileri olarak kabul edilmekte ve Q3 dergilerinde yapılan yayınlara Q1 dergilerinde yapılanların yarısı kadar puan verilmektedir.

Farklı disiplinler için aynı bibliyometrik ölçevlerin kullanıldığı yaklaşımların ciddi bir biçimde sorgulanması gerekmektedir. (Hele hele aynı bibliyometrik ölçevler kullanıldı̆̆ halde insan bilimleri alanındaki yayınların değerinin YÖK ve TÜBİTAK tarafından birbirinden oldukça farklı ağırlıklandırılmasını makul göstermek kolay değildir.) UBYT Programının ödeme miktarları temel alınacak olursa, sırf insan bilimleri dergisinde yayımlandığı için, örneğin, dilbilim konusunda yayımlanan bir makalenin sosyoloji, genetik tıp ya da yapay zekâ alanında yayımlanan bir makaleden çok daha az değerli görülmesinin bilimsel ve teknolojik gelişmeler nedeniyle farklı disiplinlerin yakınsadığı, disiplinler arası ve çok disiplinli yayınların giderek arttığı günümüzde pek savunulacak bir yanı bulunmamaktadır (Tonta ve Akbulut, 2020b).

\section{Sonuç}

TÜBİTAK UBYT Programının yeni destek algoritmasındaki en önemli değişikliklerden birisi kuşkusuz destek miktarlarını hesaplamak için doğrudan dergilerin MEP değerlerinin kullanılmaya başlanmasıdır. Böylece eski algoritmada DNP uygulaması nedeniyle özellikle tek tek yayınlara yapılan ödeme miktarlarındaki farklılıklar ortadan kaldırılmıştır. Ayrıca destek başvurularında MEP eşik değerinin uygulanmaya başlanması daha önce etki değeri düşük çok 
sayıda yayına yapılan mikro ödemelere son verilmesini sağlamıştır. Bu durum hem toplam ödeme miktarından hatırı sayılır oranda tasarruf edilmesini sağlamış hem de mikro ödemeler için harcanan zamanı ve işlem maliyetlerini azaltmıştır. 2020'de MEP eşik değerinin yeniden yükseltilmesinin toplam harcama miktarını ve maliyetleri daha da azaltması beklenmektedir.

Bunun ötesinde genel olarak bir değerlendirme yapılacak olursa; yeni destek algoritmasının dergi MEP değerlerinin yapısal özelliklerinden kaynaklanan sorunları tam olarak çözmesi mümkün değildir. Nitekim, MEP eşik değeri uygulamasına rağmen halen ödemelerin önemli bir kısmı etki değerleri nispeten düşük yayınlara yapılmaktadır. MEP eşik değeri daha da yükseltildiğinde eşik değerinin altındaki yayınlara yapılan bazı ödemelerden tasarruf sağlanacak, ama toplam ödeme miktarının önemli bir yüzdesi gene MEP değerleri dünya ortalamasının altındaki yayınlar için harcanacaktır. Çünkü diğer birçok ülkede de olduğu gibi etki değeri dünya ortalamasının üstündeki TR adresli yayınların, toplam yayınlar içindeki oranı oldukça düşüktür. UBYT Programına da yansıyan bu sorunu en azından bibliyometrik ölçevlere dayanan destek algoritmalarını değiştirerek çözmek pek mümkün gözükmemektedir.

MEP değerleriyle ilgili destek algoritması değişikliğiyle kolayca çözülemeyecek bir diğer sorun da alanlar arasındaki farklılıklardır. Halen destek miktarının büyük bir kısmı fen bilimlerindeki yayınlara harcanmaktadır. Dahası, dergilerin MEP değerlerinin sosyal bilimlerde nispeten daha düşük olması ve sanat ve insan bilimleri dergilerinin MEP değerleri olmaması nedeniyle bu alanlarda zaten az sayıda yapılan başvurulara fen bilimlerine yapılan ödemelerden daha düşük ödemeler yapılmaktadır. MEP eşik değerinin sosyal bilimler dergileri için daha düşük tutulmuş olması, Türkiye'de yayımlanan dergiler için hem MEP eşik değeri açısından hem de ödeme miktarları açısından pozitif ayrımcılık uygulanması bu sorunun farkında olunduğunun bir göstergesidir. Fakat yeni destek algoritmasının bu yönde nasıl bir etki yapacağını zaman gösterecektir. Öte yandan sanat ve insan bilimleri yayınları için belirlenen oldukça düşük ödeme miktarının dayanaklarının makul gösterilmesi gerekir.

TÜBİTAK UBYT Programı çerçevesinde işletme ve yönetim giderleri dışında 1997-2015 yılları arasında araştırmacılara 2015 yılı cari fiyatlarıyla toplam 35 milyon dolar (Tonta, 2017b, s. xiv), 2016-2019 yılları arasında da yaklaşık 70 milyon lira (Tablo 1) ödendiğini ve UBYT Programının gerek TR adresli yayın sayısının gerekse bu yayınların etkisinin artmasında pek fazla rol oynamadığını (Tonta 2017b, 2018; Tonta ve Akbulut, 2020a) da göz önünde bulundurmak gerekmektedir. UBYT Programının "fırsat maliyeti” de dikkate alındığında, arzu edilen sonuçlar alınamamasına rağmen programın başlangıcından bu yana sadece bibliyometrik ölçevlere dayanan performansa dayalı araştırma destek sistemleriyle sürdürülebilirliğinin de sorgulanması gerekmektedir.

Henüz iki yıldır uygulanan yeni destek algoritmasıyla ilgili bir yargıda bulunmak için erken olduğu düşünülebilir. Ancak yeni algoritma yukarıda anılan sorunların çözümüne katkı sağlamayacaksa o zaman "ne yapılmalı?” sorusu kuşkusuz akla gelecektir. Bunun için öncelikle performansa dayalı araştırma destek sistemlerinin dayandığı bibliyometrik ölçevlerin tam olarak neyi ölçtüğünün ve ölçülen parametrelerin destek sağlayıcıların arzu ettikleriyle uyumlu olup olmadığının dikkatle incelenmesi gerekmektedir. Bundan yaklaşık 50 yıl önce kütüphanelere koleksiyon geliştirmede yardımcı olmak için geliştirilmiş olan dergi etki faktörü (ve etki faktörüne dayanan makale etki puanı) gibi dergi düzeyi ölçevlerin tek tek makalelerin, araştırmacıların, araştırma birimlerinin performanslarını ölçmek için kullanılmasının pek de 
doğru bir yaklaşım olmadığını kabullenmek gerekmektedir (Tonta, 2014b; Tonta ve Akbulut, 2020b). Nitekim daha önce sözü edilen San Francisco ve Leiden Araştırma Değerlendirme bildirgelerinde vurgulanan husus tam da budur. Bu tür nicel ölçevler nitel değerlendirmelerin yerini almamalıdır. Ama bu bildirgeler Türkiye'deki ilgili kuruluşlar tarafından henüz yeterince değerlendirilmemiştir.

Esasen bilgiyi üreten temel kurumlar olan üniversitelerin ve araştırma merkezlerinin, iş bu bilginin etkisini ölçmeye geldiğinde deyim yerindeyse "işin kolayına kaçarak" performans ölçümlerinde, üniversite sıralamalarında vs. sadece ticari şirketler tarafından öne çıkarılan nicel ölçütleri temel olarak almaları ironiktir. Bütün araştırmacıların, bütün alanların, bütün yayın türlerinin vs. kolayca erişilebilen bibliyometrik ölçevlere göre algoritmik olarak değerlendirilebileceğini düşünmek pek doğru değildir (Tonta, 2014b, Tonta ve Akbulut, 2020b). Çin'in yakın zamanda yaptığ 1 gibi belki Türkiye'nin de Web of Science temelli performans göstergelerine "elveda" diyerek yerel araştırmaları ve farklı alanlardaki farklı çıktı (yayın vs.) türlerini güçlü bir biçimde destekleyen ve nitel ve nicel ölçütlerin dengeli bir bileşiminden oluşan bir sisteme geçmeye karar vermesinin zamanı gelmiştir. Niceliği ödüllendirmeye devam ederek niteliğin artmasını bekleyemeyiz (Civera ve diğerleri, 2020). Resmi ödül sistemleri gibi araştırma destek sistemleri de "istenen davranışları olumlu bir şekilde pekiştirmeli, aşılması gereken bir engel oluşturmamalıdır" (Kerr, 1975, s. 782). Türkiye'deki UBYT Programı, Akademik Teşvik Ödeneği Yönetmeliği gibi performansa dayalı araştırma destek sistemlerinin de bir an önce bu gözle değerlendirilmesinde yarar vardır.

\section{Teşekkür}

UBYT Programı ödeme verilerini sağlayan TÜBİTAK ULAKBİM Müdürü M. Mirat Satoğlu'ya teşekkür ederiz.

\section{Kaynakça}

2019-2021 Dönemi Yatırım Programı Hazırlama Rehberi. (2018, 10 Ekim). Resmî Gazete. Erişim adresi: http://www.resmigazete.gov.tr/eskiler/2018/10/20181011-20.pdf

Akademik Teşvik Ödeneği Yönetmeliği. (2015, 14 Aralık). Resmî Gazete (Sayı: 29566). Erişim adresi: https://www.resmigazete.gov.tr/eskiler/2015/12/20151218-4.pdf

Akademik Teşvik Ödeneği Yönetmeliği. (2016, 31 Aralık). Resmî Gazete (Sayı: 29935). Erişim adresi: https://www.resmigazete.gov.tr/eskiler/2016/12/20161231M3-2.pdf

Akademik Teşvik Ödeneği Yönetmeliği. (2018, 27 Haziran). Resmî Gazete (Sayı: 30461). Erişim adresi: https://www.resmigazete.gov.tr/eskiler/2018/06/20180627-6.pdf

Akademik Teşvik Ödeneği Yönetmeliği. (2020, 17 Ocak). Resmî Gazete (Sayı: 31011). Erişim adresi: https://www.resmigazete.gov.tr/eskiler/2020/01/20200117-9.pdf

Akın, F. (2018). Türkiye'de akademik teşvik sisteminin bilimsel çalışma performansı ile iliş̧kisi. Sakarya Üniversitesi araştırması. (Yayımlanmamış yüksek lisans tezi). Sakarya Üniversitesi, Sakarya.

Al, U., Şahiner, M. ve Tonta, Y. (2006). Arts and Humanities literature: Bibliometric characteristics of contributions by Turkish authors. Journal of the American Society for Information Science \& Technology, 57(8), 1011-1022.

Albarrán, P., Crespo, J.A., Ortuño, I. ve Ruiz-Castillo, J. (2011). The skewness of science in 219 subfields and number of aggregates. Scientometrics, 88(2), 385-397. doi: 10.1007/s11192-0110407-9

Auranen, O. ve Nieminen, M. (2010). University research funding and publication performance- An international comparison. Research Policy, 39(6), 822-834. doi: 10.1016/j.respol.2010.03.003. 
Batmaz, A. (2013, 14 Haziran). Türkiye'de bilim üretimi ve arkeoloji. Cumhuriyet Bilim ve Teknoloji, (1369), $18 . \quad$ Erişim https://www.researchgate.net/publication/255717648_Turkiye'de_Bilim_Uretimi_ve_Arkeoloji

Butler, L. (2003). Explaining Australia's increased share of ISI publications-the effects of a funding formula based on publication counts. Research Policy, 32(1), 143-155. doi: 10.1016/S00487333(02)00007-0

Butler, L. (2004). What happens when funding is linked to publication counts? H. F. Moed ve diğerleri (Yay. haz.), Handbook of quantitative science and technology research: The use of publication and patent statistics in studies of S\&T systems içinde (s. 389-405). doi: 10.1007/1-4020-2755-9

Checchi, D., Malgarini, M. ve Sarlo, S. (2019). Do performance-based research funding systems affect research production and impact? Higher Education Quarterly, 73(1), 45-69. doi: 10.1111/hequ. 12185

Civera, A., Lehmann, E. E., Paleari, S. ve Stockinger, S.A.E. (2020). Higher education policy: Why hope for quality when rewarding quantity? Research Policy, 49(8). doi: 10.1016/j.respol.2020.104083

de Rijcke, S., Wouters, P. F., Rushforth, A. D., Franssen, T. P. ve Hammarfelt, B. (2016). Evaluation practices and effects of indicator use-A literature review. Research Evaluation, 25(2), 161-169. doi: 10.1093/reseval/rvv038

Demir, S.B. (2018a). Pros and cons of the new financial support policy for Turkish researchers. Scientometrics, 116(3), 2053-2068. doi: 10.1007/s11192-018-2833-4

Demir, S.B. (2018b). A mixed-methods study of the ex post funding incentive policy for scholarly publications in Turkey. Journal of Scholarly Publishing, 49(4), 453-476. doi: 10.3138/jsp.49.4.05

Demir, S.B. (2018c). Predatory journals: Who publishes in them and why? Journal of Informetrics, 12(4), 1296-1311. doi: 10.1016/j.joi.2018.10.008

European Commission. (2010). Assessing Europe's university-based research: Expert group on assessment of university-based research (EUR24187EN). Erişim adresi: https://ec.europa.eu/research/science-society/document_library/pdf_06/assessing-europeuniversity-based-research_en.pdf

Fischer, I. ve Steiger, H-J. (2018). Dynamics of Journal Impact Factors and limits to their inflation. Journal of Scholarly Publishing, 50(1), 26-36. doi: 10.3138/jsp.50.1.06

Geuna, A. ve Martin, B. (2003). University research evaluation and funding: An international comparison. Minerva, 41(4), 277-304. doi: 10.1023/B:MINE.0000005155.70870.bd

Göksu, İ. ve Bolat, Y.İ. (2019). Akademik teşvik uygulamasının performansa yansıması: 2016 ile 2017'nin karşı1laştırmalı analizi. Yükseköğretim Dergisi, 9(2), 189-200. doi: 10.2399/yod.18.044

Harley, Y. X., Huysamen, E., Hlungwani, C. ve Douglas, T. (2016). Does the DHET research output subsidy model penalise high-citation publication? A case study. South African Journal of Science, 112(5-6), 1-3. doi: 10.17159/sajs.2016/20150352

Hedding, D.W. (2019). Payouts push professors towards predatory journals. Nature, 565(7737), 267. doi: $10.1038 / \mathrm{d} 41586-019-00120-1$

Hicks, D. (2004) The four literatures of Social Science. H. F. Moed ve diğerleri (Yay. haz.), Handbook of Quantitative Science and Technology Research: The Use of Publication and Patent Statistics in Studies of S\&T Systems içinde (s. 473-496). doi: 10.1007/1-4020-2755-9_22

Hicks, D. (2012). Performance-based university research funding systems. Research Policy, 41(2), 251261. doi: 10.1016/j.respol.2011.09.007.

Hicks, D., Wouters, P., Waltman, L., de Rijcke, S. ve Rafols, I. (2015). Bibliometrics: The Leiden Manifesto for research metrics. Nature, 520(7548), 429-431. doi: 10.1038/520429a 
Kerr, S. (1975). On the folly of A, while hoping for B. Academy of Management Journal, 9(1), 769783. Erisim adresi: http://web.mit.edu/curhan/www/docs/Articles/15341_Readings/Motivation/Kerr_Folly_of_rewa rding_A_while_hoping_for_B.pdf

Koçak, Z. (2019). Predatory publishing and Turkey. Balkan Medical Journal, 36(4), 199-201. doi: 10.4274/balkanmedj.galenos.2019.2019.4.001

Krishnarao, B. (1961, Eylül). The descriptive method in social research. Sociological Bulletin, 10(2): 46-52.

Larivière, V. ve diğerleri (2016, 11 Eylül). A simple proposal for the publication of journal citation distributions. bioRxiv, 062109. doi: 10.1101/062109

Liu, F., Guo, W. ve Zuo, C. (2018). High impact factor journals have more publications than expected. Current Science, 114(5), 955-956. doi: 10.18520/cs/v114/i05/955-956

Liu, W., Hu, G. ve Gu, M. (2016). The probability of publishing in first-quartile journals. Scientometrics, 106(3), 1273-1276. doi: 10.1007/s11192-015-1821-1

Miranda, R. ve Garcia-Carpintero, E. (2019). Comparison of the share of documents and citations from different quartile journals in 25 research areas. Scientometrics, 121(1), 479-501. doi: $10.1007 / \mathrm{s} 11192-019-03210-\mathrm{z}$

Muller, J. Z. (2019). Sayıların Diktatörlü̈̆̈̈: Başarıyı Rakamlarla Ölçme Saplantısı ve Çözüm Yolları. (A. Kamacioğlu, Çev.). İstanbul: The Kitap.

Schutt, R.K. (1999). Investigating the Social World: The Process and Practice of Research. 2d. ed. Thousand Oaks, CA: Pine Forge Press.

San Francisco Declaration on Research Assessment. (2012, 16 Aralık). Erişim adresi: http://www.ascb.org/dora

Sivertsen, G. (2016). Patterns of internationalization and criteria for research assessment in social sciences and humanities. Scientometrics, 107(2), 357-368. doi: 10.1007/s11192-016-1845-1

Sivertsen, G. (2019). Understanding and evaluating research and scholarly publishing in the Social Sciences and Humanities (SSH). Data and Information Management, 3(2), 61-71. doi: 10.2478/dim-2019-0008

Sugimoto, C. ve Larivière, V. (2018). Measuring Research: What Everyone Needs To Know. New York: Oxford University Press.

TÜBİTAK Türkiye Adresli Uluslararası Bilimsel Yayınları Teşvik (UBYT) Programı Uygulama Usul ve Esasları. (2016a). Erişim adresi: https://cabim.ulakbim.gov.tr/wpcontent/uploads/sites/4/2017/09/2016-Y\%c4\%b11\%c4\%b1-UBYT-Program\%c4\%b1Uygulama-Esaslar\%c4\%b1-2.pdf

TÜBİTAK Türkiye Adresli Uluslararası Bilimsel Yayınları Teşvik (UBYT) Programı Uygulama Usul ve Esasları. (2017a). Erişim adresi: https://cabim.ulakbim.gov.tr/wpcontent/uploads/sites/4/2019/01/UBYT_Esaslar\%c4\%b1_2016-2017_v2.pdf

TÜBİTAK Türkiye Adresli Uluslararası Bilimsel Yayınları Teşvik (UBYT) Programı Uygulama Usul ve Esasları. (2019a). Erişim adresi: https://cabim.ulakbim.gov.tr/wpcontent/uploads/sites/4/2019/05/2019_UBYT_Uygulama_Usul_ve_Esaslar1.pdf

TÜBİTAK Türkiye Adresli Uluslararası Bilimsel Yayınları Teşvik (UBYT) Programı Uygulama Usul ve Esasları. (2020a). Erişim adresi: https://cabim.ulakbim.gov.tr/wpcontent/uploads/sites/4/2020/06/2020_UBYT_Program\%c4\%b1_Uygulama_Usul_ve_Esaslar\% c4\%b1.pdf

TÜBİTAK Türkiye Adresli Uluslararası Bilimsel Yayınları Teşvik Programı Uygulama Esasları. (2015a). (237-BK EK 1). Erişim adresi: http://bit.ly/2iBw9QS 
TÜBİTAK 2016 ULAKBİM Faaliyet Raporu. (2016b). Erişim adresi: https://ulakbim.tubitak.gov.tr/sites/images/Ulakbim/ulakbim_2016_faaliyet_raporu.pdf

TÜBİTAK 2020 UBYT Programı ve dergi listesi ilan edildi (2020b, 23 Haziran). Erişim adresi: https://www.tubitak.gov.tr/tr/duyuru/tubitak-2020-ubyt-programi-ve-dergi-listesi-ilan-edildi

TÜBİTAK ULAKBIM Faaliyet Raporu 2019. (2019b). Erişim adresi: https://ulakbim.tubitak.gov.tr/sites/images/Ulakbim/tubitakulakbim-2019-faaliyet-raporu.pdf

TÜBITTAK Ulusal Akademik Ağ ve Bilgi Merkezi (ULAKBİM) Faaliyet Raporu 2017. (2017b). Erişim adresi: https://ulakbim.tubitak.gov.tr/sites/images/Ulakbim/ulakbim_fr_2017_signed.pdf

TÜBİTAK Ulusal Akademik Ağ ve Bilgi Merkezi 2015 Faaliyet Raporu. (2015b). Erişim adresi: https://ulakbim.tubitak.gov.tr/sites/images/Ulakbim/ulakbim_2015_faaliyet_raporu.pdf

TÜBİTAK Ulusal Akademik Ağ ve Bilgi Merkezi ULAKBİM Faaliyet Raporu 2018. (2018). Erişim adresi:https://ulakbim.tubitak.gov.tr/sites/images/Ulakbim/2018_tubitak_ulakbim_faaliyet_rapo ru_.pdf

Taşkın, Z. (2020). TÜBİTAK Türkiye Adresli Uluslararası Bilimsel Yayınları Teşvik Programınca desteklenen dergiler üzerine bir değerlendirme: Yayıncı ülkeler ve disiplin farklılıklarına yakından bakış. Türk Kütüphaneciliği, 34(2), 135-159. doi: 10.24146/tk.685967

Tonta, Y. (2014a). Use and misuse of bibliometric measures for assessment of academic performance, tenure and publication support. Metrics 2014: Workshop on Informetric and Scientometric Research (SIG/MET). 77th Annual Meeting of the Association for Information Science and Technology, October 31 - November 5, 2014, Seattle, WA. Erişim adresi: http://yunus.hacettepe.edu.tr/ tonta/yayinlar/tonta-asist2014-seattle-sig-met-misuse-ofbibliometric-indicators.pdf

Tonta, Y. (2014b, 3 Temmuz). Akademik performans, ögretim üyeliğine yükseltme ve yayın destekleme ölçütleriyle ilgili bir değerlendirme. Erişim adresi: http://yunus.hacettepe.edu.tr/ tonta/yayinlar/tonta-yukseltme-kriterleri-hakkindadegerlendirme-11-Temmuz-2014.pdf

Tonta, Y. (2015). Support programs to increase the number of scientific publications using bibliometric measures: The Turkish case. Salah, A. A. ve diğerleri (Yay. haz.). Proceedings of ISSI 2015 Istanbul: 15th International Society of Scientometrics and Informetrics Conference, Istanbul, Turkey, 29 June to 4 July, 2015 içinde (s. 767-777). İstanbul: Boğaziçi University. http://www.issi-society.org/proceedings/issi_2015/0767.pdf

Tonta, Y. (2017a). Türkiye'de yayımlanan ve Web of Science'ta dizinlenen dergilerle ilgili bir değerlendirme. Türk Kütüphaneciliği, 31(4), 449-482. doi: 10.24146/tkd.2017.21

Tonta, Y. (2017b). TÜBITAK Türkiye Adresli Uluslararası Bilimsel Yayınları Teşvik (UBYT) Programinin Değerlendirilmesi. Ankara: TÜBİTAK ULAKBIM. http://yunus.hacettepe.edu.tr/ tonta/yayinlar/tonta-tubitak-ubyt-programinindegerlendirilmesi.pdf

Tonta, Y. (2018a, 5 Aralık). Araştırma değerlendirme üzerine. Sarkaç. Erişim adresi: https://sarkac.org/2018/12/arastirma-degerlendirme-uzerine/

Tonta, Y. (2018b). Does monetary support increase the number of scientific papers? An interrupted time series analysis. Journal of Data and Information Science, 3(1), 19-39. doi: 10.2478/jdis-20180002

Tonta, Y. ve Akbulut, M. (2019). Does monetary support increase citation impact of scholarly papers? Catalano, G. ve diğerleri (Yay. haz.). 17th International Conference on Scientometrics \& Informetrics ISSI2019 with a Special STI Indicators Conference Track, 2-5 September 2019, Sapienza University of Rome, Italy. Proceedings içinde (s. 1952-1963). Rome: International Society for Scientometrics and Informetrics. Erişim adresi: http://www.mugeakbulut.com/yayinlar/ISSI2019_tonta_akbulut.pdf 
Tonta, Y. ve Akbulut, M. (2020a). Does monetary support increase citation impact of scholarly papers? Scientometrics, 125(2), 1617-1641. doi: 10.1007/s11192-020-03688-y

Tonta, Y. ve Akbulut, M. (2020b, 23 Eylül). Performansa dayalı akademik teşvik sistemleri üzerine. Sarkaç. Erişim adresi: https://sarkac.org/2020/09/performansa-dayali-akademik-tesviksistemleri-uzerine/

Wilsdon, J., Allen, L., Belfiore, E., Campbell, P., Curry, S., Hill, S., ... ve Tinkler, J. (2015). The Metric Tide: Report of the Independent Review of the Role of Metrics in Research Assessment and Management. England: HEFCE. doi: 10.13140/RG.2.1.5066.3520

Wouters, P. ve diğerleri. (2015). The Metric Tide: Literature Review (Supplementary Report I to the Independent Review of the Role of Metrics in Research Assessment and Management). HEFCE. doi: 10.13140/RG.2.1.5066.3520

Yaltırak, C. (2014, 21 Haziran). TÜBİTAK yayın teşvik sistemini değiştirmeli! Cumhuriyet Bilim ve Teknoloji,(1409),18.Erişimadresi:https://www.researchgate.net/publication/261061799_Tubitak _yayin_tesvik_sistemini_degistirmeli

Yokuş, G., Ayçiçek, B. ve Kanadlı, S. (2018). Akademisyen görüşleri doğrultusunda yükseköğretimde performansa dayalı akademik teşvik sisteminin incelenmesi. Yükseköğretim Dergisi, 8(2), 140149. doi: 10.2399/yod.18.007

Yuret, T. (2016). Interfield equality: Journals versus researchers. Journal of Informetrics, 10(4), 11962016. doi: 10.1016/j.joi.2016.09.004

Yuret, T. (2017). Do researchers pay attention to publication subsidies? Journal of Informetrics, 11(2), 423-434. doi: 10.1016/j.joi.2017.02.010

Zhang, L. ve Sivertsen, G. (2020). The new research assessment reform in China and its implementation. Scholarly Assessment Reports, 2(1), 3. doi: 10.29024/sar.15

Zhang, L., Rousseau, R. ve Sivertsen, G. (2017). Science deserves to be judged by its contents, not by its wrapping: Revisiting Seglen's work on journal impact and research evaluation. PLoS ONE, 12(3), e0174205. doi: 10.1371/journal.pone.0174205

\section{Summary}

Performance-based funding systems are used in many countries to reward prolific researchers. In 1993, Turkish Scientific and Technological Research Council (TÜBİTAK) has introduced an "ex post" monetary support program (UBYT) to incentivize researchers to publish in international scientific journals with impact factors. The objective of the program at the beginning was to increase the number of such papers and the program was until 2006 limited to science papers only. Since then, researchers in social sciences and humanities have also been supported.

The amount of cash support for each paper was first based on the quartiles of journals (Q1 through Q4) listed in Journal Citation Reports (JCR) under respective subject categories. However, TÜBITTAK revised the objectives of the program in 2014 so as to increase not only the quantity but also the "quality" of the TR-addressed papers and developed an algorithm to calculate the amount to be paid to each paper. The algorithm used article influence scores (AIS) of journals listed in JCR and weighted them (albeit not transparently) so that papers that appeared in journals with higher AISs would be paid higher amounts (and vice versa). Yet, this practice has been discontinued after five years, as the overwhelming majority of supported papers seemed to be published in journals with relatively lower AISs. Hence, they received even more modest rewards due to the way the algorithm functioned. In 2019, TÜBİTAK did 
away with the weighting and introduced a new algorithm based solely on journals' AISs to correct the flaws of the previous one.

Using the descriptive method, this paper compares the two support algorithms to find out if they differ in terms of supported journals, papers, and the amounts of payments. It first compares the ways the two algorithms function and provides quantitative data on JCR journals eligible for support according to each algorithm (2015-2020). It then goes on to analyze the AISs of journals and compares the amounts of support for science, social sciences and humanities journals using the new algorithm (2019). Finally, it uses the 2015 payment data obtained from TÜBITAK to find out if papers supported in 2015 would also be supported in 2019 and, if yes, how much support they would get.

The major findings of the study are as follows: It turned out that payments based on the previous algorithm did not reflect the real AISs of the three quarters of journals because of weighting. The new support algorithm is more transparent and predictable. Yet, the percentage of the total amount of support that would go to papers published in journals with AISs under the world average (1.000) do not change much (circa 75\%). This is due to the skewed distribution of journals' AISs in which TR-addressed papers tend to get published (i.e., in low impact journals), which is also the case for many other countries. As the AISs of science journals are generally higher than those of social science journals, the new algorithm, too, pays papers published in social science journals much less. The situation is even worse for arts and humanities papers: As the AISs of arts and humanities journals are not listed in JCR, the authors publishing in these journals get a rather arbitrary flat payment, which is a mere $13 \%$ of the maximum amount of support per paper.

As TÜBITAK's new support algorithm is based on journal AISs, it obviously inherits the structural problems associated with this metric such as different publishing and citation patterns observed in different scientific disciplines. Thus, the new algorithm is unlikely to alleviate the inequal amounts paid to the authors of science and social science papers, although the latter number in few. It is even more difficult to justify TÜBİTAK's decision to pay a very low flat rate for arts and humanities papers.

Findings of this study reiterate to some extent those of earlier studies in that journalbased bibliometric measures such as journal impact factors and article influence scores should not be used solely to determine the value of individual papers. Although such measures are easily available, it should be questioned as to what exactly they measure. There is no reason to believe that just because a paper on linguistics happens to be published in a humanities journal, it would be somewhat less valuable than that of a similar paper published in sociology, genetics and artificial intelligence journals. It is increasingly getting harder to defend this viewpoint, especially if we take into account of the fact that different disciplines tend to converge due to scientific and technological developments. TÜBİTAK's new support algorithm should therefore be reconsidered. 